\title{
Configurations of market environments, competitive strategies, manufacturing technologies and human resource management policies : a two-industry and two-country analysis of fit
}

Citation for published version (APA):

Heijltjes, M. G., \& van Witteloostuijn, A. (1996). Configurations of market environments, competitive strategies, manufacturing technologies and human resource management policies : a two-industry and two-country analysis of fit. NIBOR, Netherlands Institute of Business Organization and Strategy Research. NIBOR Research Memorandum No. 05 https://doi.org/10.26481/umanib.1996005

Document status and date:

Published: 01/01/1996

DOI:

10.26481/umanib.1996005

Document Version:

Publisher's PDF, also known as Version of record

Please check the document version of this publication:

- A submitted manuscript is the version of the article upon submission and before peer-review. There can be important differences between the submitted version and the official published version of record. People interested in the research are advised to contact the author for the final version of the publication, or visit the DOI to the publisher's website.

- The final author version and the galley proof are versions of the publication after peer review.

- The final published version features the final layout of the paper including the volume, issue and page numbers.

Link to publication

\footnotetext{
General rights rights.

- You may freely distribute the URL identifying the publication in the public portal. please follow below link for the End User Agreement:

www.umlib.nl/taverne-license

Take down policy

If you believe that this document breaches copyright please contact us at:

repository@maastrichtuniversity.nl

providing details and we will investigate your claim.
}

Copyright and moral rights for the publications made accessible in the public portal are retained by the authors and/or other copyright owners and it is a condition of accessing publications that users recognise and abide by the legal requirements associated with these

- Users may download and print one copy of any publication from the public portal for the purpose of private study or research.

- You may not further distribute the material or use it for any profit-making activity or commercial gain

If the publication is distributed under the terms of Article 25fa of the Dutch Copyright Act, indicated by the "Taverne" license above,

Download date: 26 Apr. 2023 
Configurations of market environments, competitive strategies, manufacturing technologies and human resource management policies: A two-industry and two country analysis of fit

M.G. Heijltjes \& A. van Witteloostuijn

$\mathrm{NIBOR} / \mathrm{RM} / 96 / 07$

http://www.unimaas.nl/ document/fdewb.htm

J.E.Lit. code: M10

$n i b \circ r$

Netherlands Institute of

Business Organization

and Strategy Research

University of Maastricht

Faculty of Economics and Business Administration

P.O. Box 616

6200 MD Maastricht

The Netherlands

Phone: ++31 43 - 3883805 
Fax : :+31 43-3258495 


\title{
CONFIGURATIONS OF MARKET ENVIRONMENTS, COMPETITIVE STRATEGIES, MANUFACTURING TECHNOLOGIES AND HUMAN RESOURCE MANAGEMENT POLICIES
}

\section{A two-industry and two-country analysis of fit}

Mariëlle HEIJLTJES

Arjen van WITTELOOSTUIJN

\begin{abstract}
In this paper an attempt is made to gain further insight into the environment-strategystructure-performance linkages. A framework is developed to relate managers' perceptions of their market environment and competitive strategies to the (advanced) production technologies and human resource management (HRM) policies their firms have adopted. Data from twelve Dutch and eight British companies in the food \& drink and chemical industries reveal that firms with coherent environment-strategy-technology-HRM 'gestalts' outperform rivals with incoherent profiles. Additionally, refined typologies of manufacturing technologies and HRM policies are proposed.
\end{abstract}

+ We gratefully thank Timothy Clark, Geoff Mallory and Derek Pugh (British Open University) for providing the British data. Of course, the usual disclaimer applies.

Correspondence: University of Limburg, Faculty of Economics and Business Administration, Department of Management Sciences, P.O. Box 616, 6200 MD Maastricht, The Netherlands. 


\title{
CONFIGURATIONS OF MARKET ENVIRONMENTS, COMPETITIVE STRATEGIES, MANUFACTURING TECHNOLOGIES AND HUMAN RESOURCE MANAGEMENT POLICIES
}

\section{A two-industry and two-country analysis of fit}

\begin{abstract}
In this paper an attempt is made to gain further insight into the environment-strategystructure-performance linkages. A framework is developed to relate managers' perceptions of their market environment and competitive strategies to the (advanced) production technologies and human resource management (HRM) policies their firms have adopted. Data from twelve Dutch and eight British companies in the food \& drink and chemical industries reveal that firms with coherent environment-strategy-technology-HRM 'gestalts' outperform rivals with incoherent profiles. Additionally, refined typologies of manufacturing technologies and HRM policies are proposed.
\end{abstract}




\section{INTRODUCTION}

A central theme in the strategy literature was, is and remains the alignment of generic and specific strategies to the environmental context. The assumption underlying a large majority of these contingency studies is that a fit between environment, strategy and structure has to be established for the organization to perform effectively. This hypothesis has through the years been supported by an uncountable number of empirical studies (e.g., Dess \& Davis, 1984; Chakravarthy, 1986; Govindarajan, 1988; Miller, 1988; McKee, Rajan Varadarajan \& Pride, 1989; Conant, Mokwa \& Rajan Varadarajan, 1990; Venkatraman \& Prescott, 1990; Habib \& Victor, 1991; Powell, 1992; Zahra \& Covin, 1993; and Schroeder, Congden \& Gopinath, 1995). The fit literature is there to stay.

The key motivation to add another study to the impressive stock of existing research is twofold. Firstly, most alignment studies focus on a few elements of the environment-strategystructure relationship only. Rarely have they addressed more than a single internal element at the functional strategy level. Although there is a somewhat larger body of research in the 'gestalt' perspective that addresses configurations of mainly environmental, strategy and structural variables simultaneously (e.g., Miller \& Friesen, 1984; Chakravarthy, 1986; and Roth, 1992), the focus in this tradition is not on the examination of the specifics of separate relationships. Since the effective implementation of strategy involves the alignment between many different elements, there is a need for empirical studies which attempt to deal with a set of elements, and thereby combine insights from the fit as 'gestalt' and fit as matching perspectives (Venkatraman, 1989). Secondly, the vast majority of empirical studies employs North-American data. Whether the various relationships between environment, strategy and structure contingencies and their impact on performance also hold for European firms has barely been tested. Especially in the light of cultural (Hofstede, 1991) and societal effects (Sorge, 1991), one would expect inter-country differences in functional strategies regarding, for example, human resource management (HRM) and manufacturing technology.

Basically, the current study is a contribution to renewing the "strategy-structureperformance paradigm" (Galunic \& Eisenhardt, 1994) by (i) applying a multi-variable and complex model of fit, (ii) taking account of multi-faceted and potentially reciprocal contingencies, (iii) developing new concepts of co-alignment elements by proposing alternative typologies and (iv) analyzing a European sample. Specifically, the present study incorporates manufacturing technology and human resource management (HRM) variables into the general environment-strategy-performance framework that dominates so much strategic management research, and explores this fit argument within the context of a BritishDutch data set. The well-established contingency prediction is, then, that firms with coherent environment-strategy-technology-HRM 'gestalts' outperform their rivals with incoherent profiles.

Note in advance that the purpose of this study is not to rigorously test these relationships, but rather to explore the complex nature of the fit between the four different elements. In this context, note also that the British and Dutch data have, by and large, been collected separately. Hence, before analyzing both subsamples a number of data inconsistencies had to be resolved. Additionally, the sample size (20 firms) is too small to permit the application of sophisticated multi-variate statistics. Notwithstanding these small sample size restrictions and data inconsistencies, we believe that the analysis below produces added value, as was 
indicated above. Additionally, given the exploratory nature of the study, the market environment, competitive strategy, manufacturing technology and HRM contingencies are framed in terms of typologies that are mostly derived empirically, albeit incorporating existing classifications.

\section{METHODOLOGY}

A study intended to investigate the complex nature of fit between four different elements, while at the same time attempting to address the conceptions of the key co-alignment variables, must be designed to explore richness of information within firms as well as patterns across firms. Therefore a balance has to be sought between the ability to identify patterns which is facilitated by a large sample - and the opportunity to obtain in-depth information which is made possible by single case studies. Consequently, the method employed here is an exploratory design involving a multi-case information base of 20 firms. In this way, typologies for co-alignment elements can be inductively derived and a detailed, in-depth study of the patterns of fit is obtainable.

\section{The sample}

The complete sample consists of thirty-eight British and Dutch business units and divisions of large companies in eight different industries. To ensure inter-country comparability of data, four criteria pertaining to the selection of companies were formulated. First, the turnover of the companies should place them among the largest 1,000 corporations in the respective country. Second, the companies have to be manufacturing companies. Third, the choice of the industrial sector in which the companies operate, is limited to eight industries. Fourth, the unit of analysis is defined as that part of the organization where management has the greatest autonomy concerning production and marketing decisions regarding (a) specific product line(s). The rationale behind this definition is to incorporate strategic choice in the analysis so as to underline that the interaction and/or coordination between internal elements is not merely determined by contingency forces, but is also based on managerial choice (Venkatraman \& Camillus, 1984).

Based on these four criteria, the selection of companies took place in a number of steps. Although a similar procedure was used in Great Britain, only the process in the Netherlands will be explained in detail here. The first step was the collection of data on the turnover of the largest corporations in the Netherlands. Starting with a list of 1990 turnovers (Financieele Dagblad, 1991) annual reports were obtained from fifty-one manufacturing organizations belonging to the Dutch top 100 companies. These reports were examined to identify potential units of analysis within the organizations. Since access to the companies appeared to be very difficult - especially because of the amount of time that was to be consumed by the investigation - and to be largely dependent on obtaining references from people known to the manager who was contacted, an initial mailing of a request to cooperate was sent to twentythree companies. Of these, eleven agreed to cooperate in the study. The second step was to extend the sample with firms outside the top 100 but with turnover over 150 million Dutch Guilders. Using the listing of 1990 turnover figures (Financieele Dagblad, 1991), again, annual reports were obtained from sixty-four companies. After the inspection of the appropriate unit of analysis within the companies and the search for people who could provide references, eleven 
requests for cooperation were mailed. This resulted in another three companies which agreed to cooperate.

To be able to study the impact of the industry environment, the analysis is mainly focused on twelve Dutch and eight British business units or divisions of the larger Dutch and British food \& drink and chemical companies. In this way, the available data enable the analysis of the research question in a two-industry, two-country context. The choice for the food \& drink and chemical industry was not arbitrary. Together these industries generated $42 \%(26.6 \%$ and $15.4 \%$, respectively) of total turnover of all manufacturing industries in the Netherlands in 1991 (CBS Statistical Yearbook, 1993). Also in Great Britain this choice is justified, since 42\% of the firms in The Times 1000 operate in either industries $(28 \%$ in the chemical industry and $14 \%$ in the food \& drink industry) (reference withheld).

Key sample characteristics are presented in the Appendix. The resulting sample size is small, since data collection was very time-consuming, for both firms and researchers. In a way, the benefit of a large sample size design was sacrificed for the sake of collecting detailed, in-depth and multi-faceted information. In this respect, as said, the data set resembles a multi-case information base.

\section{Data collection}

The data were collected in 1991-1992 by means of a questionnaire (see the Appendix) that was administered in structured interviews with the managers responsible for the diverse functional areas within the business unit or division. So, in this case, the manager responsible for strategy development - in most cases the general manager -, the production manager and the HRM manager were interviewed. Because the questions were aimed at obtaining an overview of the operations within the functional areas, the members of the management team served as experts. To obtain the information on the three functional areas, on average three interviews of approximately two hours were conducted.

The choice to interview three different managers who each addressed a different part of the questionnaire, was made to reduce one of the risks associated with key informant research: the inability of any one individual to provide accurate information on the organization as a whole (Bryman, 1989). Although the multi-person source of the data reduces the risk of common method variance (Podsakoff \& Organ, 1986), this risk could not be reduced to zero as only on HRM in the Dutch companies limited secondary data sources - in the form of annual and social reports - could be obtained. The choice for the unit of analysis - which implied conducting the interviews at the business or division level - made the collection of objective, secondary data impossible since this information is only publicly available for the corporate level.

\section{OPERATIONALIZATION OF CONSTRUCTS}

This section presents the operationalization of the market environment, generic strategies, and specific strategies in the area of manufacturing and HRM. To capture the current conceptions of these core variables within the companies interviewed, the typologies are mostly derived empirically.

\section{Market environment}


The market environment considered in this study consists of all those factors that directly influence the functioning of a division or business unit. The difficulty, however, is to conceptualize the influencing factors in such a manner that they can be related to generic and specific strategies. Consequently, this has been done in many different ways (Porter, 1980; Hambrick, 1983; Miller, 1987b \& 1988; Naman \& Slevin, 1993; and Venkatraman \& Prescott, 1990).

The market environment in this paper is characterized by two dimensions. In order to develop these dimensions the questionnaire items on the market environment were analyzed by applying PRINCALS (PRINcipal Component Analysis by means of alternating Least Squares). The PRINCALS analysis - a non-linear technique for detecting relationships within a group of numeric or categorical variables (Van den Berg, 1988) - provides an insight into how the individual competitive items are related, enabling to test the linkages between the market environment and other variables. The analysis - which is explained in detail in the Appendix suggests that two environmental dimensions emerge from the data, which together explain $69 \%$ of the variance among the items. The dimensions are interpreted as follows.

A high positive score on the first dimension implies that

* brand names of products are a key determinant in the buying process of clients;

* a favorable location of production and/or sales facilities is not important;

* the industry is strongly subsidized by the government;

* patents on the technologies of the products are important;

* buyers have no access to detailed information on demand and prices in the market; and

* easy access to raw materials is unimportant.

The first dimension mainly refers to items that affect the intrinsic operations of the company in terms of either a more conservative or a more innovative approach to cost control. For example, in a market where brand names are of no importance, government subsidies cannot be received and patents play a minor role, but clients are fully informed of market demand and prices, and both a favorable location and easy access to raw materials are necessary to compete successfully, companies hardly have any other option than to run their operations as efficiently as possible. Therefore, the first dimension can be interpreted as a continuum between "drive to cost control" (negative score on the first dimension) and "drive to innovate" (positive score on the first dimension) - i.e., as a cost dimension.

A high positive score on the second dimension implies that

* there is no aggressive use of advertising;

* entry into distribution channels is easy; and

* clients will encounter high costs if they switch to a competing supplier.

The second dimension mainly refers to items that affect the necessity for well-developed marketing and sales activities. In a market where clients must pay a high price for switching from one supplier to another, where products can be distributed without difficulty and where advertising intensity is low, the need for sophisticated marketing seems to be absent. The second dimension can therefore be interpreted as a continuum from "drive to sophisticated marketing" (negative score on the second dimension) to "drive to minimize marketing efforts" (positive score on the second dimension) - i.e., as a marketing dimension.

\section{Competitive strategy}


Strategy in this paper refers to the content of strategy at the business level - i.e., how the company is competing in selected product-market combinations. Judged by the number of typologies that are developed on this topic, it is - again - all but easy to grasp the distinguishing features of different strategies (see, for example, the studies by Miles \& Snow, 1978; Porter, 1980; Miller \& Friesen, 1986a; Herbert \& Deresky, 1987; Miller, 1987; and Morrison \& Roth, 1992). The two typologies that received most attention are Miles and Snow's (1978) and Porter's (1980). Miles and Snow (1978) distinguish four basic strategy profiles: defenders, prospectors, analyzers and reactors. Porter (1980) characterizes four generic strategies: overall cost leadership, overall differentiation, cost focus and differentiation focus. A company that fails to make a clear-cut choice is, as Porter (1980) argues, stuck in the middle. In this paper we assume, however, that combination strategies of cost leadership, differentiation and focus are sustainable. This is consistent with a contingency view of Porter's strategies (Hill, 1988; and Murray, 1988), where it is argued that the efficacy of strategies is dependent on factors associated with the structure of the industry. For example, firms operating in an environment with a drive to cost control - which stems from structural characteristics of the industry - and a drive to sophisticated marketing - which follows from the nature of the consumer market - are likely to adopt a combination strategy of cost leadership and product differentiation.

Miles and Snow's (1978) and Porter's (1980) typologies have been applied to the British and Dutch samples, respectively: in the Netherlands the companies are classified according to Porter (1980) and in Great Britain on the basis of Miles and Snow (1978). Self-typing by the general manager of the division or business unit, combined with investigator inference in Great Britain, was used in both countries to identify the strategy pursued. The main advantage of this approach is that we so capture the manager's perceptions about the current intended strategy (Snow \& Hambrick, 1980; and James \& Hatten, 1995). Since the managers were asked to classify the strategies for their most important product lines in the division or business unit they run, they can be considered experts.

Although the emphasis in the typologies of Miles and Snow (1978) and Porter (1980) is different, similarities can be traced as well. Segev (1989) compared both strategy typologies on two dimensions: internal consistency and pro-activeness. His results suggest that Miles and Snow's defender is closest to Porter's cost focus, the prospector to differentiation, the analyzer to differentiation and cost focus, and the reactor to the stuck-in-the-middle position. Apart from the strategy of stuck in the middle, which appears to be almost identical to the reactor type, none of the strategy profiles completely overlaps. They should rather be interpreted as elements of a continuum along the pro-activeness dimension. Therefore, here both classifications are not combined into a single typology.

\section{Manufacturing technology}

The technological setting, which embodies choices about the acquisition, development and deployment of manufacturing technology, is of central importance to the competitive position of organizations (Wheelwright \& Hayes, 1985; Miller, 1988; Adler, 1989; Kotha \& Orne,1989; Miller \& Roth, 1994 and Schroeder, Congden \& Gopinath, 1995). The notion that manufacturing technology should be an integral part of the competitive strategy of an organization dates back to the work of Skinner (1969), and has only received more attention since (Nemetz \& Fry, 1988; Itami \& Numagami, 1992; and Parthasarthy \& Sethi, 1992). However, although manufacturing technology is now widely recognized as an important factor 
in building a competitive advantage (Porter, 1985), much of the literature focuses on conceptual development rather than empirical research (Schroeder, 1990; and Zahra \& Covin, 1993). Of the empirical studies that have been conducted on technology, the typology by Woodward (1965) remains most well-known.

The introduction of advanced manufacturing technologies - such as, for example, Computer Aided Manufacturing and Flexible Manufacturing Systems - has significantly changed process structure since the times of Woodward's (1965) seminal study, and has created possibilities to increase the type and variety of products as well as organization scope. The adoption of advanced manufacturing technologies makes technology-strategy relationships more complex in the sense that boundaries between the traditional three technology systems are blurred, thereby making combinations of these types feasible (Jelinek \& Goldhar, 1984; Adler, 1988; and Nemetz \& Fry, 1988). Traditionally, it was assumed that when technical complexity increased, organizational flexibility decreased (Hayes \& Wheelwright, 1984). It is precisely this tradeoff of decreasing organizational flexibility and increasing technical complexity that the advanced manufacturing technologies can relax (Zammuto \& O'Connor, 1992; and Parthasarthy \& Sethi, 1993).

To analyze the technological setting of the companies in our sample, data were gathered on two topics. First, the broad production types were analyzed using a set of eleven categories similar to Woodward's (1965). In order to be able to compare the data from the two countries, however, few modifications prior to analysis had to be made. Since the set of categories applied in Great Britain differed slightly from the Dutch classification, the companies in both countries were re-assigned to the three broad categories of unit and small batch production (absent in our sample), large batch and mass production, and continuous process production in a way that is consistent with Woodward (1965). The procedure is summarized in Table 1.

\section{Insert Table 1}

Second, the impact of advanced manufacturing technologies was examined by asking the companies' product managers which advanced manufacturing technologies were in use and how they perceive their production environment. The perceptions of the production environment permitted to investigate whether the firms which implemented advanced manufacturing technologies perceived significantly different trends in the development of manufacturing technology than their non-adopting counterparts. Mann-Whitney tests on the set of statements describing developments in manufacturing technology indeed revealed significant differences (Table 2).

\section{Insert Table 2}

Subsequently, a refined classification of eight production systems was developed that incorporates the implications of the adoption of advanced manufacturing technologies in terms of the level of flexibility and integration.

\section{Large batch and mass production}

1. Modified large batch and mass production. This group contains firms that only employ 
CNC machines in production and/or MRP in their planning function. This category captures the technically least integrated and least flexible firms of the sample.

2. Automated large batch and mass production. The companies in this group integrated automation of their production function - by CNC machines and/or robots and/or CPS with automation of the design of the production process through CAPP and automation of the planning function via MRP. So, compared to the first cluster, more integration has been achieved, implying that increasing flexibility is within reach.

3. Flexible large batch and mass production. This category comprises firms that automated their production process in an integrated way through CAM - in addition to CNC machines and CPS -, the design function with CAD, CAPP and/or CAE and the planning function with MRP.

4. Innovative large batch and mass production. These companies are most advanced by integrating the three components of computer integrated manufacturing and flexibility. They automated their production function through at least the use of FMS - in addition to CAM and/or CNC machines and/or Robotics and/or CPS -, and integrated their design function with at least CAD - in addition to CAPP - and their planning function with MRP.

The four different levels of integration and flexibility in large batch and mass production should be viewed as elements of a continuum, where a company could progress from category 1 to 4 by implementing more new manufacturing technologies that enhance the level of integration and flexibility.

\section{Continuous process production}

5. Automated planning in continuous process production. This category includes companies that only automated their planning process with MRP. Advanced automation of neither the production nor of the design function was implemented.

6. Automated design in continuous process production. This group contains firms that only automated their design function with CAD, CAE and/or CAPP without automating the production or planning function.

7. Automated continuous process production. This cluster captures companies that restricted automation to their production function by implementing CPS. Automation of neither planning nor design was in use.

8. Flexible continuous process production. The companies in this category employ CAM in production in addition to CPS, automated their planning function with MRP and their design function with CAD and/or CAE.

The different levels of integration and flexibility in continuous process production cannot all reflect a continuum, since the first three categories represent the automation of just a single function of computer integrated manufacturing (Vonderembse \& White, 1991). A company can progress from automation of just a single function to multi-function integration. The fact that in continuous process production a lower variety of automation profiles is found, is not surprising. Since advanced manufacturing technologies offer opportunities for process integration and parts variety, the impact on continuous process production - where process integration is to a large extent already achieved and parts variety is thus not really permitted is limited. 
Our classification bears resemblance to the traditional division between fixed and flexible automation (Buffa \& Sarin, 1987). In fixed automation, on the one hand, the product is designed first while the automated system is utilized to produce this product as efficiently as possible. The first categories of modified large batch and mass production and automated continuous process production are closest to fixed automation, since firms in both groups have automated only parts of the production process. Flexible automation, on the other hand, is aimed at machine integration, where each automated part of the production process is programmed to perform several integrated functions. So, design is linked to production as well as to planning and control. Companies in the categories of innovative large batch and mass production and, albeit to a lesser extent, flexible continuous process production provide examples of flexible automation. The other categories of automated large batch and mass production and flexible large batch and mass production are added because a firm's technology does hardly ever fall in either of both extreme sets of categories, but is better described through visualizing a continuum from fixed to flexible automation (Parthasarthy \& Sethi, 1992). In applying this typology, assumptions as to the manufacturing objectives are imposed, however: companies in the first two large batch and mass production categories and the third continuous process production cluster emphasize the development of the production process, whereas firms in the innovative large batch and mass production and in the flexible continuous process production groups have the ability to concentrate on the development of the production process as well as on the development of products.

\section{Human resource management}

Human resource management carries the promise that if people are regarded and managed as strategic resources, this can help the firm to obtain a competitive advantage and thus superior performance (Porter, 1985). This implies that the management of personnel should be in line with the competitive strategy, since the objectives and requirements of each of the competitive strategy profiles are different (Miles \& Snow, 1984; Schuler, 1992; and Arthur, 1994). For an HRM policy to be in line with the competitive strategy, the HRM function can be centralized or decentralized depending on the dominant control mechanism implied by the competitive strategy (reference withheld). For example, the dominant control process in a cost leadership (Porter, 1980) or defender (Miles \& Snow, 1978) strategy is centralization. For the HRM function to be compatible with these strategies, a centralized process of HRM policy formulation is appropriate.

This implies that HRM policies can be classified along two dimensions: the extent of strategic integration (Schuler, 1990 \& 1992) and the degree of decentralization (Brewster \& Larsen, 1992; and Storey, 1992). From this, four different types of HRM strategies can be derived:

1. a traditional personnel management strategy, where the level of strategic integration is low and the HRM strategy is formulated in a relatively centralized manner;

2. an evolving HRM strategy, where the level of strategic integration is low but the HRM strategy is formulated in a decentralized manner;

3. an imposed HRM strategy, which is integrated with the competitive strategy but developed in a centralized manner; and

4. a true HRM strategy, which is integrated with the competitive strategy and formulated in a decentralized manner. 
In our sample the companies are classified according to these two dimensions of HRM policies. The level of strategic integration was examined qualitatively so as to reveal whether personnel is specifically considered when the general strategic objectives of the organization are discussed (Schuler, 1990 \& 1992), whether the personnel department is involved from the outset in the development of an HRM or personnel strategy and whether this strategy is written down formally. The level of decentralization was analyzed by examining the position of the personnel department within the structure of the organization (Brewster \& Larsen, 1992; and Storey, 1992). Additionally, in Great Britain questionnaire data regarding decision-making responsibility in each of the three categories of HRM choices were also analyzed: i.e., (i) recruitment and selection, (ii) performance appraisal and compensation and (iii) training and development. Note that analyses regarding the specifics of the actual implementation of the HRM components in both countries cannot sensibly be undertaken, because the mitigating effect of country-specific features such as industrial relations and education systems imposes different constraints on managerial discretion (reference withheld).

\section{Performance}

The co-alignment argument is based on the assumption that coherent environment-strategystructure 'gestalts' would result in better performance. The measurement of performance should reflect this assumption, which is however a major problem in strategy research (Chakravarthy, 1986; McGuire, Schneeweis \& Hill, 1986; and Venkatraman \& Ramanujam, 1986). The type of performance data collected in the present study is financial information in terms of Return On Sales (ROS). The source of data is (subjective) primary as in both Great Britain and the Netherlands (objective) secondary data on the profitability of business units and divisions of larger companies are not publicly available. Therefore, the managing directors of the companies were asked to provide figures on profits and sales as well as a subjective assessment of how they considered their profitability compared to competitors at home and abroad, and relative to the previous year.

From a recent study of Hoffman, Carter and Cullen (1994), we may conclude that the validity of the contemporaneous perception measures is not seriously restricted by the lack of longitudinal future performance data. Admittedly, our performance measures are not ideal. However, they are all but exceptional in the empirical literature (e.g., Robinson \& Pearce, 1988; Conant, Mokwa \& Rajan Varadarajan, 1990; Parker \& Helms, 1992; and Powell, 1992). Furthermore, they circumvent some of the problems associated with 'objective' data (Powell, 1992). Especially in comparing two countries a subjective assessment of performance is useful, since differences in accounting conventions between companies and countries can seriously diminish the objectivity of financial measures. Additionally, when the respondent is the managing director, we may assume that (s)he reasonably well informed of the financial position of her/his company. Since managing directors are involved in the strategy process, their perception of how well the company is doing is at least as important. Finally, subjective assessments of performance have been found to be consistent with objective measures (Dess \& Robinson, 1984; and Govindarajan \& Fisher, 1990). 


\section{FIVE PROPOSITIONS}

The dominant question in the present study is whether companies which have established a fit between market environment, competitive strategy, manufacturing technology and HRM policy, outperform their counterparts without such a fit in any or all of the elements. To explore this question, specific propositions can be formulated by discussing the ideal-type coalignments of the four contingencies. The key argument is summarized in Figure 1.

\section{Insert Figure 1}

Fit 1-6 reflect the bi-variate co-alignments. An overall - 'gestalt' or system - fit is obtained if all six bi-variate co-alignments are secured. In this way insights from the fit as matching and fit as 'gestalt' perspectives can be combined (Venkatraman, 1989). In four propositions, we will outline the ideal-type fit profiles building on the typologies developed in the previous section. Subsequently, a final proposition summarizes the co-alignment argument in terms of performance implications.

\section{Proposition 1}

The companies operating in a market environment with a drive to cost control and a drive to minimize marketing efforts are expected to adopt elements of Porter's (1980) cost leadership or Miles \& Snow's (1978) defender strategy. These two strategy profiles share their primary objective of minimizing cost in all areas. This emphasis on cost minimization should therefore also be reflected in the functional strategies regarding production technology and HRM. Minimizing cost in production does not, however, automatically imply that thereby development of the production process is rendered unimportant. Quite to the contrary: since process development can contribute substantially to the experience effect, it may well enhance economies of scale (Dussauge, Hart \& Ramanantsoa, 1992). Product development in the context of this strategy is aimed at reducing product cost rather than seeking completely new products (Porter, 1983). This implies long production runs of a narrow model range with little customization and infrequent design changes (Meredith \& McTavish, 1992). It is therefore expected that cost leadership is mainly associated with modified or automated manufacturing technologies. Minimizing cost in HRM implies an emphasis on control rather than development of personnel, since additional investments in personnel raise costs without immediately adding value. Furthermore, because the dominant control process in the cost leadership and defender strategies is centralization (Miles \& Snow, 1978; and Porter, 1980), a centrally developed HRM strategy is expected here. To achieve a fit with the expected manufacturing technology no extensive training seems necessary either. The use of advanced automation methods is limited, implying that the production function will not be specifically altered (Sorge, 1989; Snell \& Dean, 1992 \& 1994). This would mean that to achieve a fit between the HRM policy, manufacturing technology, competitive strategy and market environment, traditional personnel management or imposed HRM is sufficient.

Proposition 1: In a market environment characterized by a drive to cost control and a drive to minimize marketing efforts, the company should adopt a cost leadership (Porter, 1980) or defender (Miles \& Snow, 1978) strategy, employ a modified 
or automated manufacturing technology and implement traditional personnel management or imposed HRM.

\section{Proposition 2}

In a market environment characterized by a drive to innovate and a drive to minimize marketing efforts, companies should adopt competitive strategies with features of innovative differentiation, seeking to achieve a competitive advantage purely by the quality or intrinsic uniqueness of the product. Due to the nature of the market, a perceived rather than real value is hard to obtain. Neither Miles and Snow (1978) nor Porter (1980) explicitly recognize(s) a strategy with these features. Porter's (1980) differentiation strategy may fit, though, depending upon the bases of differentiation. Similarly, Miles and Snow's (1978) prospectors incorporate a number of relevant features. This emphasis on creating a real added value must also be reflected in the manufacturing strategy. This implies that development of the production process will be geared towards such issues as faster response time to orders and greater quality control (Porter, 1983; and Meredith \& McTavish, 1992). Product development will be focused on developing the required unique characteristics of the product. The manufacturing strategies most likely to be associated with the above competitive strategy profile are therefore the flexible or innovative manufacturing technologies. Similarly, the requirements for HRM policy have to be in line with the competitive strategy and manufacturing technology described above. The employees in this type of environment need to be innovative, flexible and willing to take risks. Furthermore, the HRM policy should be decentralized in line with the dominant control mechanism of the differentiation and prospector strategies. The HRM profiles that would fit with these conditions are the true and evolving HRM policies.

Proposition 2: In a market environment with a drive to innovate and a drive to minimize marketing efforts, the company should adopt a differentiation (Porter, 1980) or prospector (Miles \& Snow, 1978) strategy, employ a flexible or innovative manufacturing technology and implement a true or evolving HRM policy.

\section{Proposition 3}

In a market environment with a drive to innovate and a drive to sophisticated marketing, companies are expected to operate in a consumer market where differentiating products and creating brand loyalty are equally important. In fast-moving markets like these, where uniqueness is created through combining strong brands with development of new or existing products, companies adopt competitive strategies with characteristics of the prospector or analyzer profile (Miles \& Snow, 1978), while they could also have features of Porter's (1980) differentiation strategy. The analyzer profile is possible here as in the current type of environment a relatively stable set of products and customers can be maintained through the creation of strong brands, while at the same time new products and market opportunities can be located and exploited. The manufacturing technologies in this case will have to meet the competitive drive to innovate. In the case of the analyzer strategy, a dual technological core is required. Therefore, the flexible and innovative manufacturing technologies are most likely to provide a fit. The HRM policies appropriate to produce a consistent combination are - like in the previous proposition - the true or evolving HRM profiles. 
Proposition 3: In a market environment with a drive to innovate and a drive to sophisticated marketing, the company should adopt an analyzer, prospector (Miles \& Snow, 1978) or differentiation (Porter, 1980) strategy, employ a flexible or innovative manufacturing technology and implement a true or evolving HRM policy.

\section{Proposition 4}

In a market environment characterized by a drive to cost control in combination with a drive to sophisticated marketing, companies are expected to manufacture consumer products for which they can create a perceived added value through marketing, while at the same time keeping their prices low through cost control (Miller \& Friesen, 1986a \& 1986b). The market is conjectured to be less dynamic than the drive-to-innovate environments, with less emphasis on development of new or existing products. According to Porter (1980), companies operating under these conditions run the risk of ending up in a stuck-in-the-middle position by trying to combine two mutually exclusive strategies. As was argued previously, however, we assume that companies operating in this type of environment can indeed successfully adopt a combination strategy of cost leadership, differentiation and focus. Miles \& Snow (1978) allow a combined emphasis on cost control and sophisticated marketing in the companies pursuing an analyzer strategy. Additionally, however, they distinguish stable from dynamics domains, in which the company emphasizes different aspects, while in the type of environment in question a true combined effort is necessary. Since perceived added value can be sustained in this type of environment, the manufacturing technology will specifically have features of a cost leadership (or cost focus) strategy, since product $R \& D$ efforts are not necessarily directed towards developing new products (but to, for example, modifying existing ones). This implies that the automated or modified manufacturing technologies will suffice to create a fit with the competitive strategy. The HRM policy can take almost any form. Traditional personnel management or imposed HRM, on the one hand, will meet the competitive drive to cost control and the modified or automated manufacturing technology. The true or evolving HRM approaches, on the other hand, match with the competitive drive to sophisticated marketing, since this is associated with the differentiation and the dynamic part of the analyzer strategy. Which HRM policy will eventually provide a fit, depends on the positioning of the companies on both dimensions. It is expected that as the drive to sophisticated marketing grows stronger, more true or evolving HRM approaches are appropriate.

Proposition 4: In a market environment with a drive to cost control and a drive to sophisticated marketing, the companies should adopt an analyzer profile (Miles \& Snow, 1978) or a combination strategy of cost leadership, differentiation and focus (Porter, 1980), and employ a modified or automated manufacturing technology. The HRM policy will be of the true or evolving type as the drive to sophisticated marketing grows stronger.

\section{Proposition 5}

Propositions 1 to 4 describe four ideal-type co-alignment profiles. In a contingency framework, the logical sequel is a proposition that specifies the performance implications. Here, the standard argument (Drazin \& Van de Ven, 1985) is that firms deviating from the ideal-type fit 
profiles produce lower performance.

Proposition 5: Firms with an ideal-type co-alignment profile (Propositions 1 to 4) are associated with higher performance than their counterparts revealing inconsistencies.

The inconsistencies may follow from a misfit in any of the six bi-variate contingency linkages (Figure 1). That is, an ideal-type fit is operationalized as the absence of any bi-variate misfit. Equivalently, a deviation follows from the prevalence of any bi-variate misfit. This is, of course, a crude measure of the 'gestalt' concept of fit. However, with our data we cannot measure fine-grained distance-type of deviation proxies by applying multi-variate analysis [see, for example, Govindarajan (1988) for such an approach].

\section{Cluster analysis}

\section{RESULTS ON FIT}

How the companies in our sample - identified by a number - are positioned on the environmental dimensions and which competitive, manufacturing and HRM strategies are pursued, is presented in Figure 2.

\section{Insert Figure 2}

Cluster analysis was performed to examine a potential underlying group structure so as to enable the analysis of the competitive-manufacturing-HRM strategy combinations in their respective contexts. As suggested by many authors (e.g., Morrison \& Roth, 1992; and Reger \& Huff, 1993), a combination of a non-hierarchical method - Partitioning around Medoids (Kaufman and Rousseeuw, 1990) - and a hierarchical method - SPSS Single Linkage (SPSSX User's Guide, 1988) - was used. To determine the final cluster solution on the basis of the non-hierarchical method, the silhouette coefficient was examined for a two, three, four and five-cluster solution. The silhouette coefficient provides an indication of the average withingroup dissimilarity compared to the between-group heterogeneity. The higher the coefficient, the smaller the within-group dissimilarity compared to the between-group dissimilarity, which indicates a clear cluster structure in the data. For the hierarchical method, a large break in the squared Euclidean distance and inspection of the dendograms were used as decision criteria. The complete cluster analysis is represented in the Appendix.

For the food \& drink industry, a three-cluster solution appeared to be optimal, whereas the companies in the chemical industry were better classified in a four-cluster structure. The clusters are graphically displayed in Figure 2. To evaluate whether the companies indeed reveal consistent combinations of their market environment, competitive strategy, manufacturing technology and HRM policy, six different types of fit are analyzed (Figure 1): a fit between (i) market environment and competitive strategy (fit 1), (ii) manufacturing technology and market environment (fit 2), (iii) manufacturing technology and HRM policy (fit 3), (iv) HRM policy and competitive strategy (fit 4), (v) HRM policy and market environment (fit 5) and, finally, (vi) manufacturing technology and competitive strategy (fit 6). The results for each cluster within each industry will be discussed below. 


\section{Food \& drink industry}

The three-cluster solution has an average silhouette coefficient of 0.63. According to Kaufman and Rousseeuw (1990), who provide a subjective interpretation based on experience, this indicates that a reasonable structure has been traced. A hierarchical clustering algorithm (single linkage) confirmed the non-hierarchical solution. The first, strongest, food \& drink cluster contains a Dutch and four British firms, the second food \& drink cluster consists of three Dutch firms, while the third, weakest, food \& drink cluster captures three Dutch firms. The competitive, manufacturing and HRM strategies are presented in Table 3.

\section{Insert Table 3}

Inspection of the cluster structure yields two striking observations. Firstly, the British and Dutch firms tend to group together by country. Whether this implies that the drive to innovate is stronger in the British than in the Dutch food \& drink industry needs to be investigated further. No conclusions can as yet be drawn because of the small sample. In the remaining analysis this difference between countries does not receive particular attention. The country difference is treated as an environmental difference on the cost dimension (which also happens to differ over countries). Secondly, the difference on the marketing dimension between food \& drink clusters I and II on the one hand and cluster III on the other is proposed by Sutton (1991), too, distinguishing markets where sunk costs are exogenous - resulting from, e.g., the investment in building a plant - from markets where sunk costs are endogenous - as a result of, e.g., the investment in increasing the perceived value of products. The first type of markets can be located in homogeneous goods and horizontal product differentiation industries, whereas the second type of markets are in advertising-intensive industries [for an explanation of Sutton's (1991) theory see Boone \& Van Witteloostuijn (1995)]. Then, cluster III should consist of firms operating in homogeneous goods industries (for example, milk and sugar). Because these products are physically homogeneous, price competition is tough and differentiation, unless through regional segmentation of markets, is virtually impossible. This is true for the companies in our sample, since two commodity dairy producers and a sugar producer are located in this cluster. Firms in food \& drink clusters I and II operate in relatively advertising-intensive industries. The firms in these clusters produce liquor, beer, confectionery, frozen foods, and specialized dairy products (desserts).

In cluster I four companies - 10,11, 12 and 13-demonstrate an ideal-type fit between all the different elements: they are internally consistent (manufacturing-HRM fit) and have aligned this internal consistency with their competitive strategy and market environment. Whether company 20 can be included in this group as well remains unknown, since data on the manufacturing technology are missing. However, the elements on which information was available - competitive strategy, market environment and HRM policy - form a consistent whole. The competitive strategy matches with the conditions in the market environment, and the HRM policy is consistent with both the competitive strategy and the market environment. Finally, company 9's manufacturing technology is not advanced enough in view of the competitive strategy, market environment, HRM policy and the other competitors operating in this cluster, although the competitive strategy is aligned with the market environment and HRM policy. Company 9, therefore, is expected to perform worse than the other companies in this cluster. The results per type of fit in cluster I are summarized in Table 4A. 


\section{Insert Table 4}

Companies 14, 16 and 19 operate in cluster II. Company 16 exhibits an internal consistency in the manufacturing technology - HRM policy domains, which in turn are aligned to the market environment. None of the functional strategies, however, matches with the competitive strategy, nor is the competitive strategy in line with environmental requirements. Companies 14 and 19 theoretically reveal an ideal-type fit on all elements, and are therefore conjectured to outperform firm 16. The different types of fit in cluster II are summarized in Table 4B.

Companies 15, 17 and 18 are in food \& drink cluster III. Company 15, in a way, demonstrates an ideal-type fit between competitive strategy and market environment on the one hand and manufacturing technology and HRM policy on the other. The paradox in this company, however, is that the production technology employed - flexible continuous process production - and the HRM policy - true HRM - are too advanced for both the competitive strategy as well as the market environment. However, when the investments in technology and HRM increase efficiency to such an extent that this reinforces the effectiveness of the competitive strategy, performance will obviously not suffer since then a 'perfect gestalt' prevails. When this is not the case, and the additional investment impedes the effectiveness of a cost leadership strategy, performance will deteriorate. Company 17 suffers from a misalignment between the market environment and competitive strategy. Finally, company 18 only exhibits a fit on two elements: the manufacturing technology is aligned to the competitive strategy and the HRM policy matches with the market environment. Since this company has the least number of fits that could contribute to an internal or external consistency, performance is expected to be worse than company 15's or company 17 's. The types of fit in cluster III are summarized in Table 4C.

Summarizing, it is expected that - based on the fit between the market environment, competitive strategy, manufacturing technology and HRM policy - the best performing companies in the food \& drink sector are firms 10,11, 12, 13 in cluster I and companies 14 and 19 in cluster II. The specific hypotheses on performance implications are summarized in Table 5, which specifies Proposition 5.

\section{Insert Table 5}

\section{Chemical industry}

The four-cluster solution found in the chemical industry has an average silhouette coefficient of 0.40, which according to Kaufman and Rousseeuw (1990) indicates that the structure is weak and could be artificial. However, the hierarchical clustering algorithm (single linkage), again, confirmed the non-hierarchical result. Also in the chemical industry the British and Dutch firms group together. Chemical clusters I and II contain only British firms and chemical clusters III and IV only Dutch companies. But, as in the food \& drink sector, this difference is merely treated here as an environmental difference rather than as a difference between countries. The competitive, manufacturing and HRM strategies are presented in Table 6.

\section{Insert Table 6}

An examination of the cluster structure yields the observation that all the chemical clusters, but one, operate in an environment with a drive to minimize marketing efforts. This is not 
surprising since due to the industrial nature of the market, fierce advertising is an unlikely method of communicating. In a market where real value - in terms of specifications of the product - is more important than perceived value - in terms uniqueness created through advertising - personal selling is preferred (Hutt \& Speh, 1986). Cluster II is the odd one out because of its score on drive to sophisticated marketing. A possible explanation could be that because the firm in this cluster operates in one of the downstream chemical sectors, a strong identification with final customers' needs, beyond just the technical specifications of the product, is necessary (APPE, 1993).

Chemical cluster I includes two companies. On the one hand, company 1 reveals internally consistent policies regarding manufacturing and HRM, although the production technology does not match the competitive strategy. Company 2 , on the other hand, suffers from various inconsistencies. This firm can benefit from only two fits, between technological setting and market environment on the one hand and HRM and competitive strategy on the other. The HRM policy - competitive strategy pair, however, cannot deal with the requirements of the market environment, nor can it support the production technology employed. It is therefore expected that this company will perform worse than its competitor in this cluster. The types of fit present in chemical cluster I are summarized in Table 7A.

\section{Insert Table 7}

Cluster II is a singleton, consisting of company 3 only. Although a comparison with intra-group competitors is thus unattainable, this firm is expected to perform well since it demonstrates an ideal-type fit between all the linkages analyzed. The types of fit for this company are summarized in Table 7B.

Cluster III captures three firms, of which none obtained an ideal-type match between all the elements. Company 4 is internally consistent with regard to its HRM policy, which matches with the competitive strategy as well as the market environment. A misfit exists, however, concerning the manufacturing technology. Modified large batch and mass production is not advanced enough to fit with the environmental conditions as this technology profile impedes the proper implementation of a differentiation focus strategy. Company 6 suffers from inconsistencies, too. Although the HRM policy is aligned to the competitive strategy, and the technological setting fits with the environmental conditions, a misfit prevails with regard to the competitive strategy and market environment. So, both companies, 4 and 6, are not expected to obtain high performance. Company 8 , finally, has missing data on the technological setting. The HRM policy, however, is aligned to the competitive strategy. The fit between competitive strategy and market environment is doubtful, since a differentiation strategy is pursued in an environment with a slightly larger emphasis on cost control rather than on sophisticated marketing. Therefore, despite the missing data, the performance of this company is expected to be below average. The types of fit in this cluster are summarized in Table 7C.

Finally, chemical cluster IV includes companies 5 and 7. Company 5 exhibits an ideal-type alignment of all the elements. Hence, company 5 is expected to be among the better performing firms. Company 7 employs flexible continuous process production, which is too advanced for the competitive strategy and market environment unless the main goal of the investments was to increase efficiency. So, high performance in this case only occurs if the efficiency objective is realized and the technology investment costs incurred are offset. The types of fit in this cluster are summarized in Table 7D. 
Summarizing, we expect that - based on the types of fit - the best performing firms in the chemical industry are companies 3 and 5 . These hypotheses on performance implications are summarized in Table 8, which reflects a specification of Proposition 5.

\section{Insert Table 8}

\section{RESULTS ON PERFORMANCE}

\section{Country differences}

Because the data on performance are gathered in two countries and they could thus be subject to diverging accounting legislation and practice, potential differences between Great Britain and the Netherlands are examined first. Since Mann-Whitney tests indicate that significant differences in ROS and subjective measures exist between Great Britain and the Netherlands on the one hand and between the industries on the other, the performance implications are evaluated within the country, industry and cluster context. So high or low performance is considered relative to the country and industry averages the companies operate in. The average return on sales per industry in both countries are listed in Table 9.

\section{Insert Table 9}

The subjective self-report measures of profitability are only used to investigate differences between the clusters in the food \& drink and chemical industries. The number of companies is too limited to perform non-parametric tests within the clusters. Between-cluster comparisons are analyzed with two-tailed Mann-Whitney statistics. Another issue relates to size effects. Within countries, there is no significant effect of firm size on performance. The size effect coincides with country differences: i.e., the British firms are significantly larger than the companies in the Dutch subsample. Hence, by controlling for country differences the size effect is taken into account. Note, finally, that for the sake of the argument's style the following description may now and then suggest causalities. Strictly speaking, of course, our crosssection data cannot reveal such causalities.

\section{Food \& drink industry}

The ROS of the food \& drink companies together with the British and Dutch industry averages are presented in Table 10A. Of the six companies that operate in food \& drink cluster I, four companies - 10,11, 12 and 13 - demonstrate an ideal-type fit. Company 9 was expected to be the worst performer in this cluster. Predictions on the performance of company 20 were hard to make, since data on the technological setting are missing. Companies 9 to 13 are of British origin, while company 20 is Dutch. When the ROS for each company in the cluster is calculated, it indeed appears that all companies with an ideal-type alignment but one are among the best performers. ROS for companies 10 to 13 are $0.12,0.12,0.08$ and 0.1 , respectively. It is surprising that company 12 has an ROS of 0.08 , which makes this firm albeit still performing above the Dutch national average - one of the lowest performers in the British food \& drink sample. Although the number of fits cannot offer a satisfactory explanation 
for this phenomenon, it is striking that the highest performers, with an ROS of 0.12 , both employ innovative large batch and mass production technologies, whereas companies 12 and 13 both have a flexible large batch and mass production technology. So, perhaps only investments in the most advanced production technology generate above-average performance in this type of environment, thereby making even flexible large batch and mass production not advanced enough. It remains surprising, though, that company 9 still reveals an ROS of 0.08 . The only Dutch company in the cluster, 20 , has an ROS of 0.07 , which is equal to the Dutch industry average. Probably, this firm has a production technology that meets at least some of the requirements posed by the competitive strategy and market environment. The manufacturing technology may not be advanced enough, though, to contribute to superior performance.

Food \& drink cluster II contains three Dutch companies. Based on the analysis of the types of fit, companies 14 and 19 were expected to outperform company 16. When the ROS of the companies is examined, this indeed appears to be the case. Although ROS data for company 19 are missing, company 14 reported one of the highest ROS figures of the Dutch food \& drink sample. It appears that an HRM policy that theoretically is too advanced, does not impede but indeed does contribute to superior performance. Company 16 reveals an ROS that belongs to the lowest in the Dutch sample. To increase performance, this firm should either adapt the manufacturing technology - HRM profile configuration to the competitive strategy, and move out of the environment with an extreme drive to cost control, or adapt the competitive strategy to the current market environment, HRM policy and manufacturing technology.

Finally, food \& drink cluster III comprises three Dutch firms. Company 15 was expected to outperform companies 17 and 18 if the investments in manufacturing technology and HRM would contribute to greater efficiency. When the ROS for these companies is examined, this conjecture is confirmed. Company 15 , with an ROS of 0.13 , is the best performer of the entire British and Dutch food \& drink sample. Like company 14 in cluster II, this firm invested more in HRM than theoretically required by the market environment and competitive strategy. Additionally, the production technology seemed to be too advanced as well. Also in this case, however, rather than constraining performance the additional investments may have contributed to superior performance. The misalignment of various elements in company 18 makes it the worst performer in the industry with an ROS of -0.01 . This company can truly be considered 'stuck in the middle' (Porter, 1980) or classified as a reactor strategist (Miles \& Snow, 1978), since neither internal consistency among HRM policy and production technology, nor external consistency in meeting environmental requirements nor any consistency with the competitive strategy can be witnessed.

Apart from performance differences within the clusters, between-cluster differences were investigated. Although cluster I, on average, has the highest ROS $(0.1)$ and cluster III the lowest (0.06) - cluster II ranks in between with an average ROS of 0.07 -, no significant difference in ROS between the clusters could be detected. When the subjective self-reports were evaluated, however, significant between-cluster differences appear on all three measures. The companies in cluster II are significantly $(p=0.0356)$ more confident that their profitability is high relative to their national competitors, if compared with the firms in cluster I ranking second - and cluster III. Considering the Dutch companies in cluster II and III, this finding is supported by the average ROS for these clusters. The same result appears if profitability compared to last year is analyzed $(p=0.0882)$. When, however, profitability 
relative to foreign competitors is considered, the best performing cluster in terms of ROS group I - feels least secure about profitability.

\section{Chemical industry}

The ROS of the chemical companies, again together with British and Dutch industry averages, are presented in Table 10B. Of the two British companies that operate in chemical cluster I, company 1 was expected to outperform company 2. Company 2, similar to food \& drink company 18, suffered from various inconsistencies. Analysis of the ROS for both companies supports this hypothesis. On the one hand, company 1 obtained an ROS of 0.23 , the highest value in the entire chemical sample. Perhaps, the strategy implemented by this firm differs from the strategy formally stated. Company 2, on the other hand, suffers from the worst performance in the British chemical sample, with an ROS of 0.01 . This company can be considered 'stuck in the middle' (Porter, 1980) or pursuing a reactor strategy (Miles \& Snow, 1978) by revealing an inconsistent manufacturing technology - HRM policy configuration that is aligned to neither the competitive strategy nor the market environment in any systematic way. Furthermore, this firm's competitive strategy does not meet the requirements posed by the market environment.

Singleton chemical cluster II consists of the British firm 3. This company demonstrates an ideal-type alignment between all the elements investigated. Company 3 matches an analyzer strategy with an innovative large batch and mass production technology and a true HRM policy in a market environment that is particularly characterized by a drive to sophisticated marketing. Although firm 3's ROS cannot be compared to other companies operating under similar conditions in our sample, performance - with an ROS of 0.12 - is as expected, and equal to the British industry average.

Cluster III holds three Dutch firms that were all expected to perform below average, although for company 8 the hypothesis was tentative due to missing data on the technological setting. The ROS for company 4 and $6,0.01$ and -0.03 , respectively, indeed suggest that these companies suffer from inferior performance. Company 8 , however, has an ROS of 0.03 , which is above the Dutch industry average. Apparently, this firm employs a manufacturing technology - modified large batch and mass production - that fits with the market environment, reflecting a slight emphasis on a drive to cost control, while at the same time maintaining enough flexibility to pursue a differentiation strategy.

Chemical cluster IV comprises Dutch companies 5 and 7. Because company 5 has perfectly matched all the elements investigated, it was expected to outperform company 7 , which invested more than required by the competitive strategy or market environment in advanced technology and revealed a questionable manufacturing technology- HRM policy fit. The ROS for both companies, however, is equally high - 0.05 in both cases. So, like in food \& drinks, company 15 reveals an additional investment in advanced technology that is associated with superior performance. Companies that employ flexible continuous process production apparently perform well, even when traditional personnel management is employed. This could indicate that the impact of advanced manufacturing technologies on HRM is only limited in continuous process production.

Finally, performance, in terms of ROS and subjective self-report measures on profitability, between the clusters was analyzed without producing any significant difference. So, in the chemical industry the differences within clusters are larger than between clusters. 


\section{CONCLUSION}

In both industries, Proposition 5, arguing that companies which aligned the different contingency elements into a perfectly consistent profile would gain above-average performance, is in general confirmed by our analysis. In the food \& drink industry, three companies with an ideal-type fit - companies 10 and 11 in cluster I and company 14 in cluster II - gained above-average performance. In the chemical industry, two above-average performing companies with ideal-type alignments - company 3 in cluster II and company 5 in cluster IV - were detected. Furthermore, two companies for which an ideal-type fit was doubtful in the sense that they may have overinvested in either production technology or HRM are among the above-average performers. Food \& drink company 15 employs true HRM and flexible continuous process production while traditional personnel management and any less sophisticated production technology would have been sufficient. Chemical company 7 implemented flexible continuous process production while the requirements posed by the market environment and competitive strategy could be met with a less advanced production system.

This distinction detected in our sample is similar to two categories that Chakravarthy (1986) distinguishes when measuring the quality of a firm's transformation. He identifies 'adaptive specialization' and 'adaptive generalization'. Adaptive specialization, on the one hand, refers to the process of improving the goodness of fit in a given situation. This applies to all the companies with an ideal-type match in our sample. Adaptive generalization, on the other hand, refers to the investment in a surplus of 'slack resources', which enables the firm to improve its ability to adapt to changing conditions. This apparently is the case with the companies in our sample that overinvested, although, of course, by applying ROS as the performance measure only companies that successfully created and utilized these slack resources are recognized as such. Firms that are in the process of investing in manufacturing technology and/or HRM, and therefore suffer from worse performance in the year investigated, will not be detected. Besides the companies that performed above average, two reactors (Miles \& Snow, 1978) or 'stuck-in-the-middle' companies (Porter, 1980) are identified. Food \& drink company 18 and chemical firm 2 both suffer from internal inconsistencies that are matched with neither the competitive strategy nor the market environment. Therefore, they suffer from inferior performance.

Basically, the present study offers a threefold contribution to the literature. First, the analysis applies a multi-fit framework that takes account of functional strategies as to manufacturing technology and HRM policy, together with the standard contingencies of competitive strategy and market environment. Second, on the basis of the data two refined typologies, of manufacturing technologies and HRM policies, are developed. Third, the five propositions are confronted with a European - i.e., British and Dutch - rather than NorthAmerican set of firms. Although the results presented in this study are promising in the search for an integration between the fit as matching and fit as 'gestalt' perspective, they remain preliminary for at least three reasons.

1. A serious limitation of the analysis is that no conclusions can be drawn as to what percentage of performance is explained by the six types of fit investigated, or which type of fit contributes most or least to performance. The data set at this point is too limited to perform multi-variate analysis. Here, the analysis would benefit from an enlarged sample 
of firms.

2. Data on whether a stated strategy is actually implemented are not available. An illustration of this is chemical company 1 , for which we expect that the competitive strategy implemented differs from the one formally stated, since the functional strategies regarding manufacturing technology and HRM policy are internally consistent and aligned to the environment. The questionnaire employed needs improvement on this point in order to be able to establish a sounder strategic profile.

3. The measure of performance used, ROS, is too restricted and needs to move to a multifaceted proxy that includes, apart from multiple measures of financial performance, nonfinancial data as well. Since the objectives the companies pursue with their strategies are hardly ever limited to financial criteria, performance measures should therefore include a broader perspective, too.

Another limitation relates to Galunic and Eisenhardt's (1994) diagnosis of the current state of the art of the contingency "paradigm": the present study is cross section rather than longitudinal. Therefore, we plan to replicate this study in the near future. Then, we will hopefully be able to improve the sample size, implementation data and performance measurement as well. 


\section{REFERENCES}

Adler, P.S. (1988), Managing Flexible Automation, California Management Review, 30, 34-56.

Adler, P.S. (1989), Technology Strategy: Guide to the Literature, in: Research on Technological

Innovation, Management and Policy: A Research Annual, Rosenbloom, R.S. and

Burgelman,R.A. (eds), JAI Press, Greenwich, CT, 1-25.

APPE: Association of Petrochemical Producers in Europe (1993), Activity Review 1992-1993: Adapting to the Global Market, CEFIC, Brussels.

Arthur, J.B. (1994), Effects of Human Resource Systems on Manufacturing Performance and Turnover, Academy of Management Journal, 37, 670-687.

Berg van den, G. (1988), PRINCALS voor Beginners, Department of Data Theory, University of Leiden, RR-88-11.

Boone, C.A.J.J., Witteloostuijn, van A. (1995), Industrial Organization and Organizational Ecology: The Potential for Cross-Fertilization, Organization Studies, 16, 265-298.

Brewster, C., Larsen, H.H. (1992), Human Resource Management in Europe: Evidence from Ten Countries, International Journal of Human Resource Management, 3, 409-434.

Bryman, A. (1989), Research Methods and Organization Studies, Unwin Hyman, Boston.

Buffa, E.S., Sarin, R.K. (1987), Modern Production/Operations Management, Wiley, New York.

CBS (1993), Statistical Yearbook, The Hague.

Chakravarthy, B.S. (1986), Measuring Strategic Performance, Strategic Management Journal, 7, $437-$ 458.

Clark, T., Mallory, G., Pugh, D. (1993), International Organizational Observatory: British Feedback Report No. 1, School of Management, The Open University, Great Britain.

Conant, J.S., Mokwa, M.P., Rajan Varadajaran, P.R. (1990), Strategic Types, Distinctive Marketing Competencies and Organizational Performance: A Multiple Measure-Based Study, Strategic Management Journal, 11, 365-383.

Dess, G.G., Davis, P.S. (1984), Porter's (1980) Generic Strategies as Determinants of Strategic

Group Membership and Organizational Performance, Academy of Management Journal, 27,

467488.

Dess, G.S., Robinson, R.B. (1984), Measuring Organizational Performance in the Absence of Objective Measures, Strategic Management Journal, 5, 265-273.

Drazin, R., Van de Ven, A.H. (1985), Alternative Forms of Fit in Contingency Theory, Administrative Science Quarterly, 30, 514-539.

Dussauge, P., Hart, S., Ramanantsoa, B. (1992), Strategic Technology Management, Wiley New

York.

Financieele Dagblad (1991), De Omzet Cijfers van 1990, 19 November 1991, Amsterdam.

Galunic, D.C., Eisenhardt, K. (1994), Renewing the Strategy-Structure-Performance Paradigm, Research in Organizational Behavior, 16, 215-255.

Govindarajan, V. (1988), A Contingency Approach to Strategy Implementation at the Business- Unit Level: Integrating Administrative Mechanisms with Strategy, Academy of Management Journal, 31, 828-853.

Govindarajan, V., Fisher, J. (1990) , Strategy, Control Systems and Resource Sharing: Effects on Business-Unit Performance, Academy of Management Journal, 33, 259-285.

Habib, M.M., Victor, B. (1991), Strategy, Structure and Performance of US Manufacturing and

Service MNCs: A Comparative Analysis, Strategic Management Journal, 12, 589-606.

Hambrick, D. (1983), An Empirical Typology of Mature Industrial-Product Environments, Academy of Management Journal, 26, 213-230.

Hayes, R.H., Wheelwright, S.C. (1984), Restoring our Competitive Edge: Competing through Manufacturing, Wiley, New York.

Heijltjes, M.G. (1995), Organizational Fit or Failure: Competitive Environments, Generic and Specific Strategies in Great Britain and the Netherlands, Universitaire Pers Maastricht, Maastricht.

Heijltjes, M.G., Sorge, A.M., Witteloostuijn, van A. (1993), International Organizational Observatory: Descriptive Report The Netherlands, Faculty of Economics and Business Administration, University of Limburg, Maastricht.

Heijltjes, M.G., Witteloostuijn, van A., Sorge, A. (1996), Human Resource Management in Relation to Generic Strategies: A Comparison of Chemical and Food \& Drink Companies in the Netherlands and Great Britain, International Journal of Human Resource Management, 7, 383-412.

Herbert, T.T., Deresky, H. (1987), Generic Strategies: An Empirical Investigation of Typology Validity and Strategy Content, Strategic Management Journal, 8, 135-147.

Hill, C.W.L. (1988), Differentiation Versus Low Cost or Differentiation and Low Cost: A Contingency 
Framework, Academy of Management Review, 13, 401-412.

Hoffman, J.J., Carter, N.M., Cullen, J.B. (1994), The Test of Lag-Structure Identification when

Testing for Fit, Organization Studies, 15, 829-848.

Hofstede, G. (1991), Cultures and Organizations: Software of the Mind, McGraw-Hill, London.

Hutt, M.D., Speh, T.W. (1986), Industrial marketing Management: a Strategic View of Business

Markets, 2nd edition, Dryden, Chicago.

Itami, H., Numagami, T. (1992), Dynamic Interaction between Strategy and Technology, Strategic Management Journal, 13, 119-135.

James, W.L., Hatten, K.J. (1995), Further Evidence on the Validity of the Self Typing Paragraph

Approach: Miles and Snow Strategic Archetypes in Banking, Strategic Management Journal,

161-168.

Jelinek, M., Goldhar, J.D. (1984), The Strategic Implications of the Factory of the Future, Sloan

Management Review, Summer, 29-37.

Kaufman, L., Rousseeuw, P.J. (1990), Finding Groups in Data: An Introduction to Cluster Analysis, Wiley, New York.

Kotha, S., Orne, D. (1989), Generic Manufacturing Strategies: A Conceptual Synthesis, Strategic Management Journal, 10, 211-231.

McGuire, J., Schneeweis, T., Hill, J. (1986), An Analysis of Alternative Measures of Strategic Performance, Advances in Strategic Management, 4, 127-154.

McKee, D.O., Rajan Varadarajan, P., Pride, W.M. (1989), Strategic Adaptability and Firm Performance: A Market Contingent Perspective, Journal of Marketing, 53, 21-35.

Meredith, J., McTavish, R. (1992), Organized Manufacturing for Superior Performance, Long Range Planning, 25, 63-71.

Miles, R.E., Snow, C.C. (1978), Organizational Strategy, Structure and Process, McGraw-Hill, New York.

Miles, R.E., Snow, C.C. (1984), Designing Strategic Human Resource Systems, Organizational Dynamics, Summer, 36-52.

Miller, D. (1987), The Structural and Environmental Correlates of Business Strategy, Strategic Management Journal, 8, 55-76.

Miller, D. (1988), Relating Porter's Business Strategies to Environment and Structure: Analysis a n d Performance Implications, Academy of Management Journal, 31, 280-308.

Miller, D., Friesen, P.H. (1984), A Longitudinal Study of the Corporate life Cycle, Management Science, 10, 1161-1183.

Miller, D., Friesen, P.H. (1986a), Porter's (1980) Generic Strategies and Performance: An Empirical Examination with American Data. Part 1: Testing Porter, Organization Studies, 7, 37-55.

Miller, D., Friesen, P.H. (1986b), Porter's (1980) Generic Strategies and Performance: An Empirical Examination with American Data. Part 2: Performance Implications, Organization Studies, 7, 255-261.

Miller, J.G., Roth, A.V. (1994), A Taxonomy of Manufacturing Strategies, Management Science, 40, 285304.

Morrison, A.J., Roth, K. (1992), A Taxonomy of Business-Level Strategies in Global Industries, Strategic Management Journal, 13, 399-418.

Murray, A.I.(1988), A Contingency View of Porter's "Generic Strategies", Academy of Management Review, 13, 390-400.

Naman, J.L., Slevin, D.P. (1993), Entrepreneurship and the Concept of Fit: A Model and Empirical Tests, Strategic Management Journal, 14, 137-153.

Nemetz, P.L., Fry, L.W. (1988), Flexible Manufacturing Organizations: Implications for Strategy

Formulation and Organization Design, Academy of Management Review, 17, 86-111.

Parker, B., Helms, M.M. (1992), Generic Strategies and Firm Performance in a Declining Industry, Management International Review, 32, 23-39.

Parthasarthy, R., Sethi, S.P. (1992), The Impact of Flexible Automation on Business Strategy and Organizational Structure, Academy of Management Review, 17, 86-111.

Parthasarthy, R., Sethi, S.P. (1993), Relating Strategy and Structure to Flexible Automation: A Test of Fit and Performance Implications, Strategic Management Journal, 14, 529-549.

Podsakoff, P.M., Organ, D.W. (1986), Self-Reports in Organizational Research: Problems and Prospects, Journal of Management, 12, 531-544.

Porter, M.E. (1980), Competitive Strategy: Techniques for Analyzing Industries and Competitors, The Free Press, New York.

Porter, M.E. (1983), The Technological Dimension of Competitive Strategy, Research on Technological Innovation, Management and Policy: A Research Annual, Rosenbloom R.S. and Burgelman, R.A. (eds), JAI Press, Greenwich, CT, 1-33. 
Porter, M.E. (1985), Competitive Advantage: Creating and Sustaining Superior Performance, The Free Press, New York.

Powell, T.C. (1992), Organizational Alignment as Competitive Advantage, Strategic Management Journal, 13, 119-134.

Reger, R.K., Huff, A.S. (1993), Strategic Groups: A Cognitive Perspective, Strategic Management Journal, 14, 103-124.

Robinson, R.B., Pearce, J.A. (1988), Planned Patterns of Strategic Behavior and their Relationship to Business-Unit Performance, Strategic Management Journal, 9, 43-60.

Roth, K. (1992), International Configuration and Coordination Archetypes for Medium-Sized Firms in Global Industries, Journal of International Business Studies, 3, 533-549.

Schroeder, D.M. (1990), A Dynamic Perspective of the Impact of Process Innovation upon Competitive Strategies, Strategic Management Journal, 11, 25-41.

Schroeder, D.M., Congden, S.W., Gopinath, C. (1995), Linking Competitive Strategy and Manufacturing Process Technology, Journal of Management Studies, 32, 163-189.

Schuler, R.S. (1990), Repositioning the Human Resource Function: Transformation or Demise?,

Academy of Management Executive, 4, 49-60.

Schuler, R.S. (1992), Strategic Human Resource Management: Linking the People with the Strategic Needs of the Business, Organizational Dynamics, Summer, 18-32.

Segev, E. (1989), A Systematic Comparative Analysis and Synthesis of Two Business-Level Strategic Typologies, Strategic Management Journal, 10, 487-505.

Skinner, W. (1969), Manufacturing: Missing Link in Corporate Strategy, Harvard Business Review,47, 136-145.

Snell, S.A., Dean, J.W. (1992), Integrated Manufacturing and Human Resource Management: A

Human Capital Perspective, Academy of Management Journal, 35, 467-504.

Snell, S.A., Dean, J.W. (1994), Strategic Compensation for Integrated Manufacturing: The Moderating Effects of Jobs and Organizational Inertia, Academy of Management Journal, $\mathbf{5}$, 1109-1140.

Sorge, A. M. (1989), An Essay on Technical Change: Its Dimensions and Social and Strategic Context, Organization Studies, 10, 23-44.

Sorge, A. M. (1991), Strategic Fit and the Societal Effect: Interpreting Cross-National Comparisons of Technology, Organization and Human Resources, Organization Studies, 12, 161-190.

SPSS-X Users's Guide (1988), SPSS-X User's Guide, 3rd edition, SPSS Inc., Chicago.

Storey, J. (1992), Developments in the Management of Human Resources, Blackwell, Oxford.

Sutton, J. (1991), Sunk Costs and Market Structure: Price Competition, Advertising and the Evolution of Concentration, MIT Press, Cambridge, MA.

Venkatraman, N. (1989), The Concept of Fit in Strategy Research: Toward Verbal and Statistical Correspondence, Academy of Management Review, 14, 423-444.

Venkatraman, N., Prescott, J.E. (1990), Environment-Strategy Coalignment: An Empirical Test of its Performance Implications, Strategic Management Journal, 11, 1-23.

Venkatraman, N., Ramanujam, V. (1986), Measurement of Business Performance in Strategy Research: A Comparison of Approaches, Academy of Management Review, 11, 801-814.

Venkatraman, N., Camillus, J.C. (1984), Exploring the Concept of "Fit" in Strategic Management, Academy of Management Review, 9, 513-525.

Vonderembse, M.A., White, G.P. (1991), Operations Management: Concepts, Methods and Strategies, 2nd edition, West Publishing, St. Paul, MN.

Wheelwright, S.C., Hayes, R.H. (1985), Competing through Manufacturing, Harvard Business Review, January-February, 99-108.

Woodward, J. (1965), Industrial Organization: Theory and Practice, Oxford University Press, New York.

Zahra, S.A., Covin, J.G. (1993), Business Strategy, Technology Policy and Firm Performance, Strategic Management Journal, 14, 451-478.

Zammuto, R.F., O'Connor, E.J. (1992), Gaining Advanced Manufacturing Technologies' Benefits: The Roles of Organization Design and Culture, Academy of Management Review, 17,701-728. 


\section{APPENDIX}

The characteristic sample statistics of British and Dutch companies in the chemical and food \& drink sample are listed in Table A1.

\begin{tabular}{|c|c|c|c|c|c|}
\hline Number & Nationality & Industry & $\begin{array}{l}\text { Size in } \\
\text { number of employees }\end{array}$ & Type of product & $\begin{array}{l}\text { Main target } \\
\text { market }\end{array}$ \\
\hline 1 & British & Chemicals & 25,800 & $\begin{array}{l}\text { Bulk \& specialty } \\
\text { chemicals }\end{array}$ & Industrial \\
\hline 2 & British & Chemicals & 3,061 & Bulk chemicals & Consumer \\
\hline 3 & British & Chemicals & 1,100 & $\begin{array}{l}\text { Bulk \& specialty } \\
\text { chemicals }\end{array}$ & Consumer \\
\hline 4 & Dutch & Chemicals & 308 & Specialty chemicals & Industrial \\
\hline 5 & Dutch & Chemicals & $\begin{array}{l}\text { Missing for company: } \\
25,000 \text { for entire group }\end{array}$ & Bulk chemicals & Industrial \\
\hline 6 & Dutch & Chemicals & 161 & $\begin{array}{l}\text { Bulk \& specialty } \\
\text { chemicals }\end{array}$ & Industrial \\
\hline 7 & Dutch & Chemicals & 270 & Bulk chemicals & Industrial \\
\hline 8 & Dutch & Chemicals & 1,950 & Bulk chemicals & Consumer \\
\hline 9 & British & Food \& drinks & 744 & Specialty teas & Consumer \\
\hline 10 & British & Food \& drinks & 1,723 & $\begin{array}{l}\text { Alcoholic \& non- } \\
\text { alcoholic beverages }\end{array}$ & Consumer \\
\hline 11 & British & Food \& drinks & 12,000 & Confectionery & Consumer \\
\hline 12 & British & Food \& drinks & 6,001 & Frozen foods & Consumer \\
\hline 13 & British & Food \& drinks & 2,524 & Confectionery & Consumer \\
\hline 14 & Dutch & Food \& drinks & 434 & $\begin{array}{l}\text { Alcoholic \& non- } \\
\text { alcoholic beverages }\end{array}$ & Consumer \\
\hline 15 & Dutch & Food \& drinks & 1,270 & $\begin{array}{l}\text { Basic food product in } \\
\text { bulk }\end{array}$ & Consumer \\
\hline 16 & Dutch & Food \& drinks & 162 & Frozen potato products & Consumer \\
\hline 17 & Dutch & Food \& drinks & 360 & Dairy products & Consumer \\
\hline 18 & Dutch & Food \& drinks & $\begin{array}{l}\text { Missing for company: } \\
7,077 \text { for entire group }\end{array}$ & Dairy products & Consumer \\
\hline 19 & Dutch & Food \& drinks & 100 & Dairy products & Consumer \\
\hline 20 & Dutch & Food \& drinks & 1,100 & Confectionery & Consumer \\
\hline
\end{tabular}

Table A1:

Sample characteristics of the British and Dutch companies in the chemical and food \& drink industry.

\section{QUESTIONNAIRE}

The data in this paper are collected by means of a structured questionnaire which was developed by the International Organizational Observatory (IOO). The $\mathrm{IOO}$ is a group of organizational researchers based in six European business schools. The group was inaugurated by CRORA, Bocconi University, Milan, Italy. Apart from the items addressed in this paper, the 100 questionnaire covers issues of structure, $\mathrm{R} \& \mathrm{D}$, control and information systems (reference withheld). Data collection in the British companies was performed by the British team at the Open University.

Although the questionnaire used in Great Britain and the Netherlands is the same on most topics, also slight differences exist. In this case, the questions for both countries are presented. The original 
language of the Dutch questionnaire is Dutch. It has been translated for this paper.

\section{Market environment: Great Britain and the Netherlands}

How would you characterize the competitive environment of the organization?

Use the following scale from 1 to 4: 1 =incorrect description and 4=correct description.

1. Brand name is an important element in the buying process of clients.

2. Clients face high switching cost when they consider changing suppliers.

3. There are obvious difficulties in getting access to some distribution channels.

4. Economies of scale in production can be obtained.

5. The possession of patents is important.

6. A favorable location of production plants and/or sales facilities is important.

7. Large government subsidies are a feature of this industry.

8. The industry has a limited growth rate, which makes it difficult to absorb a new competitor without an adverse affect on the sales and trading results.

9. The products we buy from our supplier determine the quality of the product we manufacture.

10. Fierce advertising battles are a feature of this industry.

11. The competitors in this industry are not highly diversified.

12. Companies in this industry have recently increased their production capacity considerably.

13. Competition from producers of substitutes of our products increases.

14. Our product has a strong influence on the quality of our customer's product or service.

15. The customer has detailed information on demand and market prices.

16. Easy access to raw materials is important.

17. In this industry, companies generally are in a strong position to withstand a new competitor.

18. To operate in this industry it is essential to be able to call on the combined resources of a national group or network of companies.

19. To operate in this industry it is essential to be able to call on the combined resources of a multinational group or network of companies located in different countries.

\section{Competitive strategy}

\section{The Netherlands}

1. For your most important product lines, do you pursue a strategy mainly based on cost leadership or leadership in quality?

2. Is your strategy directed at a specific segment of the market?

\section{Great Britain}

1. What is your current strategy?

[The answers of the companies were classified by the British researchers according to the main characteristics which Miles \& Snow (1978) mention for each of the strategy types].

\section{Manufacturing technology: Great Britain and the Netherlands}

\section{Production system}

I. How would you characterize your organization's primary manufacturing technology?

In Great Britain companies chose one description that best characterized their production system; in the Netherlands companies indicated on a scale from 1 (correct description) to 4 (incorrect description) how much truth they contained.

1. Output is individually produced to the specification of an individual or small groups of customers.

2. Output is produced in batches of 500 or less.

3. Output is produced in larger batches but they tend to be modular, consisting of both standardized components and components produced for customers' specification.

4. Output is produced in very large batches or on a mass production basis and the products change very little over time.

5. Output is produced in very large batches or on a mass production basis, but new products are often brought out.

6. Output is for gaseous, viscous or solids and is produced using continuous process technology. 
II. To what extent do you use design and development tools and systems such as the following: Use the following scale: $0=$ not in use, $1=$ used as experiment only, and $2=$ used.

1. Computer Aided Design (CAD): an information system to facilitate the design and modeling of products.

2. Computer Aided Manufacturing (CAM): an information system that controls manufacturing machinery in an integrated manner.

3. Computer Aided Engineering (CAE): an information system to assist in the examining and testing of design from a structural or engineering point of view.

4. Material Requirement Planning (MRP): an information system to support the planning of materials.

5. Computer Aided Process Planning (CAPP): an information system to support the design of the production process.

6. Robotics: automation of a specific part of the production process.

7. Flexible Manufacturing Systems (FMS): a collection of robots or CNC machines that can be employed in a flexible manner.

8. Computer Numerical Control (CNC): a machine tool that is directly linked to a computer that controls it.

9. Continuous Process Software (CPS): software that controls the production process in continuous process production.

\section{Developments in the production environment}

Given the current state of production technologies how do the following statements apply to your organization? Great Britain: 1=incorrect description to 5=correct description; the Netherlands: 1=correct description to 4=incorrect description.

1. The number of products is increasing.

2. The number of variants from standard is increasing.

3. Products are becoming more standardized.

4. The time between the initial idea for new products and when they enter production is becoming longer.

5. Work in progress and stocks of materials are being reduced.

6. Inventories of finished goods are being reduced.

7. Batch size is increasing.

8. The stages of the production process are becoming more closely integrated (from either the organizational or technical point of view).

9. There is a steady increase in the number of people involved in the design and development compared with numbers involved in production.

10. There is steady increase in the number of people involved in planning and scheduling the production process compared with numbers involved in production.

11. The management of materials, components and work in progress is becoming decentralized to work stations/groups.

12. Plant and equipment are being used more intensively.

13. The variety and diversity of skills needed to produce output are increasing.

14. The previous statement has been largely resolved by subcontracting specific tasks.

\section{Personnel management/HRM}

\section{The Netherlands}

The level of strategic integration and decentralization was examined qualitatively by interviewing personnel/HRM managers and examining annual reports, internal company documents and recruitment brochures. The level of strategic integration was determined by (i) whether personnel is specifically considered when general strategic objectives of the organization is discussed, (ii) the personnel department is involved from the outset in the development of an HRM or personnel strategy and (iii) whether this strategy is formally written down. The level of decentralization was determined by examining the position of the personnel department within the structure of the organization.

\section{Great Britain}

Only questionnaire data could be used.

\section{Strategic integration}


1. Was the personnel department involved in the development of an HRM or personnel strategy from the outset?

2. Was this strategy formally written down?

\section{Decentralization}

Indicate for each of the following categories of personnel:

a. Senior management.

b. Personnel department.

c. Line management.

d. First line supervisors.

e. Other.

1. Who is primarily responsible for the recruitment of different grades of employees?

2. Who is primarily responsible for regulating employee departures of different grades of employees?

3. Who has overall responsibility for career development policies?

4. Who has overall responsibility for training?

\section{Performance: Great Britain and the Netherlands}

1. Profit before tax.

2. Sales.

3. How does your organization's profitability compare with the following benchmarks?

Use a scale from 1 (much worse) to 5 (much better).

Other firms in the same sector?

Other foreign firms in the same sector?

The previous year?

\section{PRINCALS ENVIRONMENT VARIABLES}

PRINCALS stands for "PRINcipal Component Analysis by means of alternating Least Squares". It is a non-linear technique for detecting relationships within a group of numeric or categorical variables (van den Berg, 1988). The list of variables used in the analysis, their number of categories and the marginal frequencies are presented below in Tables A2 and A3 respectively. The variables in this analysis were treated as nominal instead of ordinal, because the category quantifications after initial analysis appeared to be equal on many variables. This indicates that the imposed order of the categories does not allow for an optimal solution. Treating the variables as nominal allows PRINCALS the freedom to adopt an ordering that leads to an optimal solution. The examination of the category quantifications also leads to the deletion of seven variables from the initial variable list. On these variables the distinction between the supposedly opposite categories of 'correct' and 'incorrect' was insufficient. The seven deleted variables are the following:

1. The products that the company buys from its most important supplier also determine the quality of the company's final product

2. An increase in the scale of production will lead to a considerable decrease in the average costs per unit produced

3. Competition intensifies due to an increase in the number and/or power of substitute products

4. The industry's product influence to a large extent the quality of the products of clients

5. It is hard for other companies to enter the industry because of the existence of considerable resources sunk in the companies already present in the industry

6. There is only slow growth in the industry, implying that only limited entry accommodation can occur without this having an impact on the sales of established companies

7. The companies in the industry have recently increased their productive capacity substantially.

Finally, on the basis of examining the category quantifications, the categories 'slightly correct' and 'slightly incorrect' were combined into a category 'undecided'. 


\begin{tabular}{||l|l|c|l||}
\hline Variables & Variable label & Number of categories & Measurement level \\
\hline Name1 & Brand name & 3 & Single nominal \\
\hline Loc1 & Favorable location & 3 & Single nominal \\
\hline Subs1 & Government subsidies & 3 & Single nominal \\
\hline Patent1 & Exclusive technologies & 3 & Single nominal \\
\hline Cust1 & Customer information & 3 & Single nominal \\
\hline Swcost1 & Switching costs & 3 & Single nominal \\
\hline Entry1 & Distribution channels & 3 & Single nominal \\
\hline Raw1 & Access to raw materials & 3 & Single nominal \\
\hline Adver1 & Advertising is fierce & 3 & Single nominal \\
\hline
\end{tabular}

Table A2: $\quad$ List of variables used in PRINCALS analysis

\begin{tabular}{|c|c|c|c|c|}
\hline \multicolumn{5}{|c|}{ Marginal frequencies } \\
\hline \multirow[t]{2}{*}{ Variable } & \multirow[t]{2}{*}{ Missing } & \multicolumn{3}{|l|}{ Categories } \\
\hline & & 1 & 2 & 3 \\
\hline Name1 & 0 & 6 & 17 & 15 \\
\hline Loc1 & 0 & 11 & 20 & 7 \\
\hline Subs1 & 0 & 13 & 8 & 17 \\
\hline Patent1 & 0 & 9 & 18 & 11 \\
\hline Cust1 & 0 & 8 & 18 & 12 \\
\hline Swcost1 & 0 & 16 & 19 & 3 \\
\hline Entry1 & 0 & 16 & 18 & 4 \\
\hline Raw1 & 0 & 17 & 14 & 7 \\
\hline Adver1 & 0 & 19 & 11 & 8 \\
\hline
\end{tabular}

Table A3: $\quad$ Categories and marginal frequencies used in PRINCALS

The analysis performed with the list of final variables, results in a solution with two optimal dimensions that together explain $69 \%$ of the variance. The associated eigenvalues are presented in Table A4. 


\begin{tabular}{||l|l|}
\hline Dimension & Eigenvalue \\
\hline 1 & .4479 \\
\hline 2 & .2428 \\
\hline
\end{tabular}

Table A4: Eigenvalues of environmental dimensions

A third dimension was not included because its eigenvalue of 0.1055 does not meet the criterion of $1 /$ number of variables $(9)=0.1111$. To determine which variables load on which dimensions, the highest component loading for each dimension is divided by two. This results in a cut-off point of 0.4305 for dimension 1 and a cut-off point of 0.4295 for dimension 2. Although 'switching cost' on dimension 1 does meet this criterion, it was not included in the analysis because of the large discrepancy with the other loadings. The component loadings for the different variables are summarized in Table A5.

\begin{tabular}{|c|c|c|c|c|}
\hline \multicolumn{5}{|c|}{ Component loadings } \\
\hline \multicolumn{2}{|l|}{ Variable } & \multicolumn{2}{|l|}{ Dimension 1} & Dimension 2 \\
\hline \multicolumn{2}{|l|}{ Name1 } & \multicolumn{2}{|l|}{$.692^{*}$} & -.347 \\
\hline \multicolumn{2}{|l|}{ Loc1 } & \multicolumn{2}{|l|}{$-.792^{*}$} & .132 \\
\hline \multicolumn{2}{|l|}{ Subs1 } & \multicolumn{2}{|l|}{$.738^{*}$} & -.376 \\
\hline \multicolumn{2}{|l|}{ Patent1 } & \multicolumn{2}{|l|}{$.846^{*}$} & -.060 \\
\hline \multicolumn{2}{|l|}{ Cust1 } & \multicolumn{2}{|l|}{$-.746^{*}$} & -.426 \\
\hline \multicolumn{2}{|l|}{ Swcost1 } & \multicolumn{2}{|l|}{.480} & $.612^{\star *}$ \\
\hline \multicolumn{2}{|l|}{ Entry1 } & \multicolumn{2}{|l|}{-.358} & $-.764^{\star *}$ \\
\hline \multicolumn{2}{|l|}{ Raw1 } & \multicolumn{2}{|l|}{$-.861^{*}$} & .158 \\
\hline \multicolumn{2}{|l|}{ Adver1 } & \multicolumn{2}{|l|}{.090} & $-.859^{\star *}$ \\
\hline Iteration number & Total fit & Total loss & Multiple loss & Single loss \\
\hline 25 & .6906 & 1.3094 & 1.2304 & .0790 \\
\hline
\end{tabular}

${ }^{*}=$ variable belongs to dimension 1

** $=$ variable belongs to dimension 2

Table A5: $\quad$ Components loadings of environmental variables

\section{CLUSTER ANALYSIS}

The objective of cluster analysis is to form groups of objects in such a way that objects in the same group are similar to each other, whereas objects in different groups are as dissimilar as possible. Two clustering algorithms were used. One partitioning method, Partitioning around Medoids (Kaufman \& Rousseeuw, 1990) and one hierarchical method, SPSS Single Linkage (SPSS-X User's Guide, 1988).

Although the partitioning method was applied to two to five clusters, for reasons of brevity only characteristics of the chosen cluster solution are presented here. For the hierarchical method the complete analysis is reported. 
Food \& drinks

I. Partitioning around medoids for $k=3$

The three resulting clusters have the following characteristics:

* Cluster 1 is isolated, with diameter 1.05 and separation 1.21

* Cluster 2 is not isolated, with diameter 0.87 and separation 0.84

* Cluster 3 is isolated, with diameter 1.14 and separation 0.84

The silhouette width of the clusters is then determined to examine the composition and strength of the three clusters. The results are presented in Table A6. The analysis reveals that Cluster I has an average silhouette width of 0.75 , Cluster II has an average silhouette width of 0.57 and Cluster III has and average silhouette width of 0.46 . For the entire data set, the average silhouette width is 0.63 .

\begin{tabular}{|c|c|c|c|}
\hline & & & $\begin{array}{llllllllllllllllllllllllll}0 & 0 & 0 & 0 & 0 & 0 & 0 & 0 & 0 & 0 & 0 & 0 & 0 & 0 & 0 & 0 & 0 & 0 & 0 & 0 & 0 & 0 & 0 & 0 & 0 & 1 \\
. & . & . & . & . & . & . & . & . & . & . & . & . & . & . & . & . & . & . & . & . & . & . & . & . & . \\
0 & 0 & 0 & 1 & 1 & 2 & 2 & 2 & 3 & 3 & 4 & 4 & 4 & 5 & 5 & 6 & 6 & 6 & 7 & 7 & 8 & 8 & 8 & 9 & 9 & 0 \\
0 & 4 & 8 & 2 & 6 & 0 & 4 & 8 & 2 & 6 & 0 & 4 & 8 & 2 & 6 & 0 & 4 & 8 & 2 & 6 & 0 & 4 & 8 & 2 & 6 & 0\end{array}$ \\
\hline Cl uster & Nei gh & $S(1)$ & $\mathrm{H}+\mathrm{H}+\mathrm{H}+\mathrm{H}+\mathrm{H}+\mathrm{H}+\mathrm{H}+\mathrm{H}+\mathrm{H}+\mathrm{H}+\mathrm{H}+\mathrm{H}+\mathrm{H}+\mathrm{H}+\mathrm{H}+\mathrm{H}$ \\
\hline & bour & & + \\
\hline 1 & 3 & .82 & $\mathrm{ana}+* * * * * * * * * * * * * * * * * * * * * * * * * * * * * * * * * * * * * * * * * * *$ \\
\hline 1 & 3 & .82 & ana $+* * * * * * * * * * * * * * * * * * * * * * * * * * * * * * * * * * * * * * * * * * * *$ \\
\hline 1 & 3 & .82 & ana $+* * * * * * * * * * * * * * * * * * * * * * * * * * * * * * * * * * * * * * * * * * *$ \\
\hline 1 & 2 & .79 & ana $+* * * * * * * * * * * * * * * * * * * * * * * * * * * * * * * * * * * * * * * * * *$ \\
\hline 1 & 2 & .78 & ana $+* * * * * * * * * * * * * * * * * * * * * * * * * * * * * * * * * * * * * * * * *$ \\
\hline 1 & 3 & .44 & $\begin{array}{l}\mathrm{dcf}+* * * * * * * * * * * * * * * * * * * * * * \\
\quad+\end{array}$ \\
\hline 2 & 3 & .68 & $\mathrm{dcf}+* * * * * * * * * * * * * * * * * * * * * * * * * * * * * * * * * * * *$ \\
\hline 2 & 3 & .63 & $\mathrm{dcf}+* * * * * * * * * * * * * * * * * * * * * * * * * * * * * * *$ \\
\hline 2 & 3 & .40 & $\begin{array}{l}\mathrm{df} 0+* * * * * * * * * * * * * * * * * * * * \\
+\end{array}$ \\
\hline 3 & 1 & .49 & $\mathrm{dcf}+* * * * * * * * * * * * * * * * * * * * * * * *$ \\
\hline 3 & 2 & .47 & $\mathrm{col}+* * * * * * * * * * * * * * * * * * * * * * *$ \\
\hline 3 & 2 & .42 & $\begin{array}{l}\mathrm{df} \mathrm{o}+* * * * * * * * * * * * * * * * * * * * * * \\
+\end{array}$ \\
\hline
\end{tabular}

ana $=$ analyzer, $\mathrm{dcf}=$ combination of differentiation, cost leadership and focus, dfo= differentiation focus, col=cost leadership

Table A6: $\quad$ Silhouette of three food \& drink clusters using PAMS

The proposed decision criteria according to Kaufman and Rousseeuw (1990) are summarized in Table A7.

\begin{tabular}{||l|l||}
\hline \hline Silhouette Coefficient & Proposed interpretation \\
\hline $0.71-1.00$ & A strong structure has been found \\
\hline $0.51-0.70$ & A reasonable structure has been found \\
\hline $0.26-0.50$ & $\begin{array}{l}\text { The structure is weak and could be artificial, please try } \\
\text { additional methods on this dataset }\end{array}$ \\
\hline$<0.26$ & No substantial structure has been found \\
\hline
\end{tabular}

Table A7: $\quad$ Interpretation of silhouette coefficients (Kaufman and Rousseeuw, 1990) 
Taking the criteria of Table A7 into account the cluster structure in the food \& drink industry can be considered reasonable. Nonetheless also a hierarchical clustering method is performed to check whether the same results appear. This procedure is summarized below.

\section{Single linkage}

The agglomeration schedule using single linkage is summarized in Table A8.

\begin{tabular}{|c|c|c|l|l|l||}
\hline Stage & Cluster 1 & Cluster 2 & Squared Euclidean distance & $\begin{array}{l}\text { 1st appearance in } \\
\text { cluster 1 }\end{array}$ & $\begin{array}{l}\text { 1st appearance in } \\
\text { cluster 2 }\end{array}$ \\
\hline 1 & 2 & 3 & 0.008865 & 0 & 0 \\
\hline 2 & 1 & 4 & 0.009814 & 0 & 0 \\
\hline 3 & 1 & 5 & 0.051307 & 3 & 0 \\
\hline 4 & 1 & 2 & 0.121834 & 0 & 1 \\
\hline 5 & 6 & 11 & 0.287085 & 5 & 0 \\
\hline 6 & 6 & 8 & 0.369407 & 0 & 0 \\
\hline 7 & 7 & 10 & 0.429542 & 4 & 0 \\
\hline 8 & 1 & 12 & 0.484588 cut-off & 7 & 0 \\
\hline 9 & 7 & 9 & 0.675804 & 6 & 9 \\
\hline 10 & 6 & 7 & 0.721426 & 8 & 10 \\
\hline 11 & 1 & 6 & 1.476125 & & 0 \\
\hline
\end{tabular}

Table A8: $\quad$ Agglomeration schedule food \& drink clusters

The associated dendogram using single linkage in which can be seen how the clusters are formed is presented in Table A9.

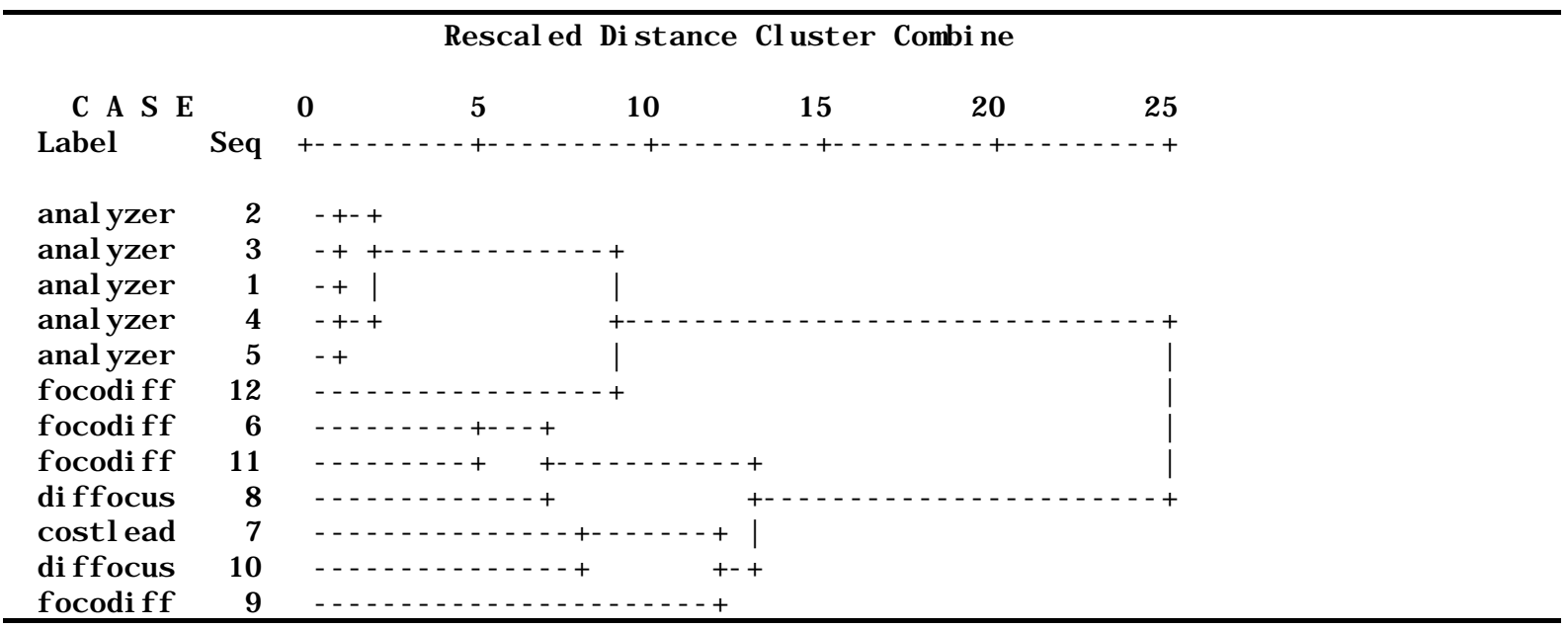

Table A9: $\quad$ Dendogram food \& drink clusters

The resulting cluster membership of cases is summarized in Table A10. 


\begin{tabular}{|c|c|c|c|c|}
\hline Label & Case & 4 clusters & 3 clusters & 2 clusters \\
\hline analyzer & 1 & 1 & 1 & 1 \\
\hline analyzer & 2 & 1 & 1 & 1 \\
\hline analyzer & 3 & 1 & 1 & 1 \\
\hline analyzer & 4 & 1 & 1 & 1 \\
\hline analyzer & 5 & 1 & 1 & 1 \\
\hline differentiation, cost leadership and focus & 6 & 2 & 2 & 2 \\
\hline cost leadership & 7 & 3 & 3 & 2 \\
\hline differentiation focus & 8 & 2 & 2 & 2 \\
\hline differentiation, cost leadership and focus & 9 & 4 & 3 & 2 \\
\hline differentiation focus & 10 & 3 & 3 & 2 \\
\hline differentiation, cost leadership and focus & 11 & 2 & 2 & 2 \\
\hline differentiation, cost leadership and focus & 12 & 1 & 1 & 1 \\
\hline
\end{tabular}

\section{Table A10: $\quad$ Cluster membership food \& drink companies}

From the agglomeration schedule - which shows the stages of clustering and the proximity values at which items combine to form new clusters -, the dendogram - which graphically displays the stages of clustering - and the cluster membership, it can be concluded that three is the optimal number of clusters in the food \& drink industry.

\section{Chemicals}

I. Partitioning around Medoids for $k=4$

The four clusters distinguished in the chemical industry have the following characteristics:

Cluster 1 is isolated with diameter 0.69 and separation 0.94

Cluster 2 is isolated, it is a singleton with separation 1.79

Cluster 3 is not isolated with diameter 1.25 and separation 0.94

Cluster 4 is isolated with diameter 0.71 and separation 1.18

The silhouette width of the clusters is then examined to determine the composition and the strength of the clusters. The silhouette coefficients are presented in Table A11. The analysis reveals that cluster I has an average silhouette width of 0.55 , cluster II has an average silhouette width of 0.00 , cluster III has an average silhouette width of 0.32 and cluster IV has an average silhouette width of 0.56 . For the entire data set in chemicals, the average silhouette width is then 0.40 . When the proposed decision criteria according to Kaufman and Rousseeuw (1990) are examined (Table: D.2) it has to be concluded that the cluster structure is weak and could be artificial. 


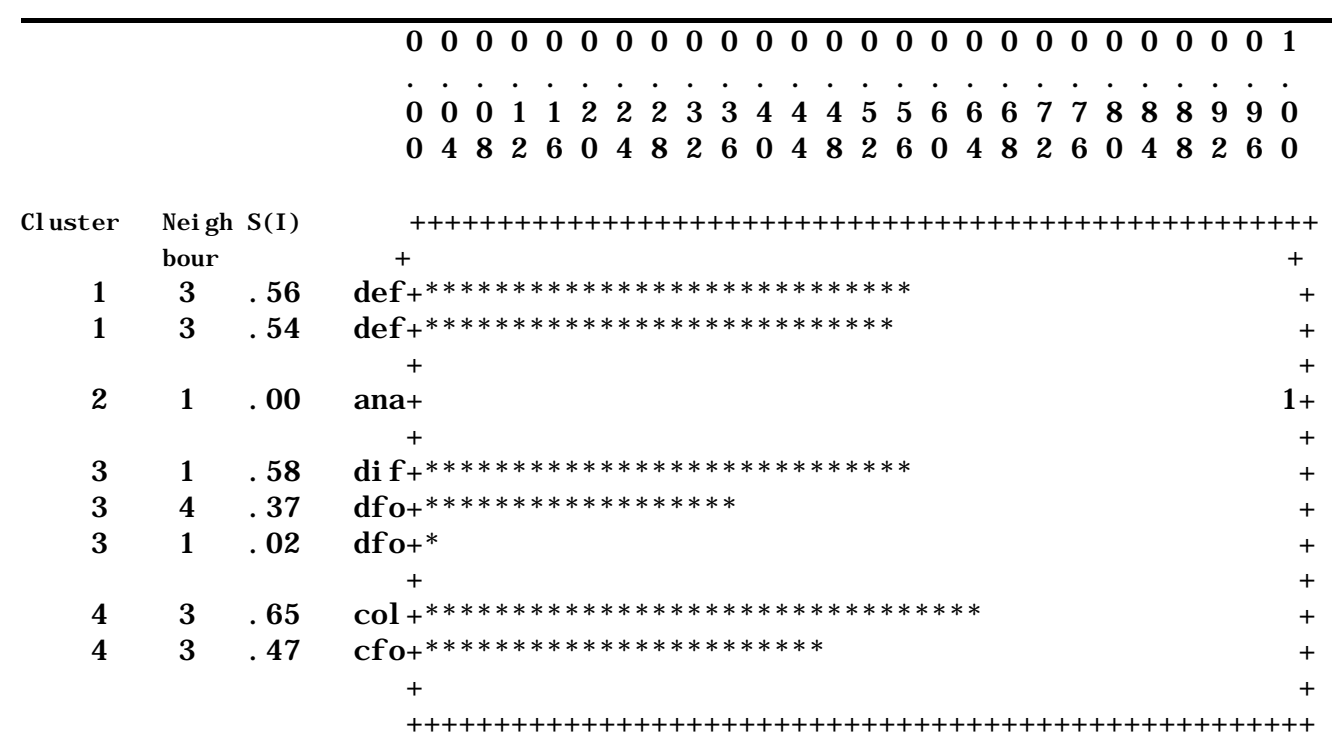

def=defender, ana=analyzer, dif=differentiation, $d f o=$ differentiation focus, col=cost leadership, $\mathrm{cfo}=$ cost focus

Table A11: $\quad$ Silhouette of four chemical clusters

Therefore additional analysis, by means of a hierarchical methods, is necessary. The results of the hierarchical method are presented in the following.

II Single linkage

The agglomeration schedule using single linkage for the chemical industry is presented in Table A12.

\begin{tabular}{||l|l|l|l|l|l||}
\hline Stage & Cluster 1 & Cluster 2 & Squared Euclidean distance & $\begin{array}{l}\text { 1st appearance } \\
\text { cluster 1 }\end{array}$ & $\begin{array}{l}\text { 2nd appearance cluster } \\
2\end{array}$ \\
\hline 1 & 4 & 8 & 0.360625 & 0 & 0 \\
\hline 2 & 4 & 6 & 0.464462 & 1 & 0 \\
\hline 3 & 1 & 2 & 0.472802 & 0 & 0 \\
\hline 4 & 5 & 7 & 0.506497 cut off & 0 & 0 \\
\hline 5 & 1 & 4 & 0.877026 & 3 & 2 \\
\hline 6 & 1 & 5 & 1.400777 & 5 & 4 \\
\hline 7 & 1 & 3 & 3.206482 & 6 & 0 \\
\hline
\end{tabular}

Table A12: $\quad$ Agglomeration schedule for chemical clusters 
The associated dendogram using single linkage is presented in Table A13.

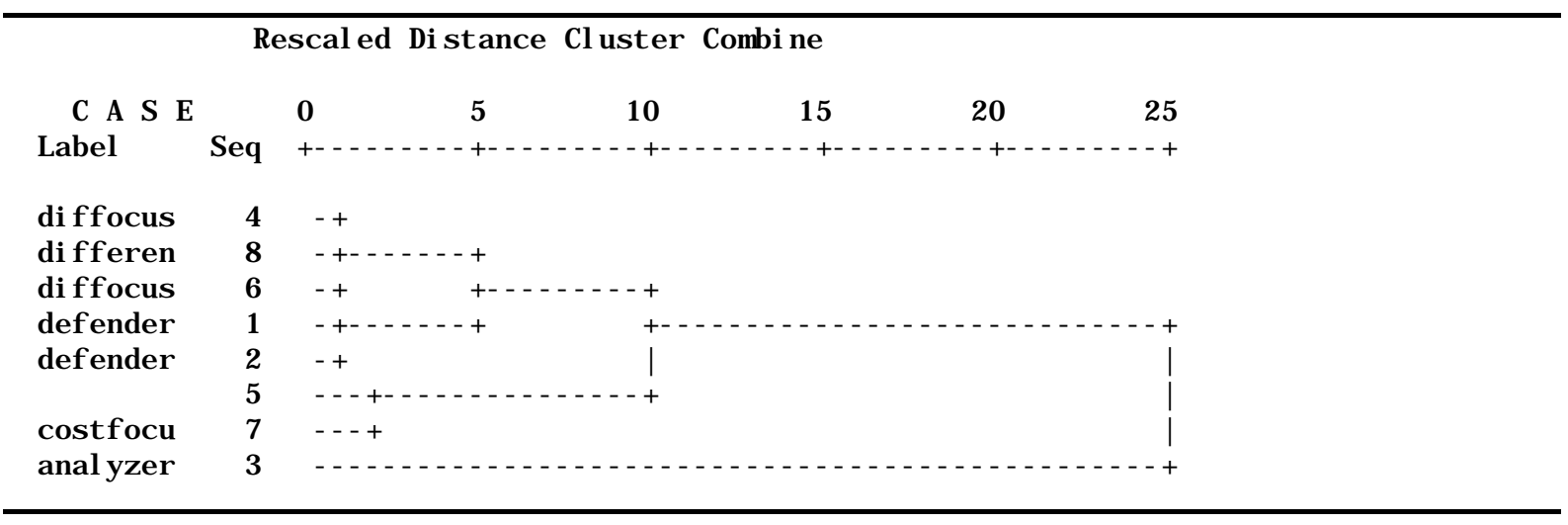

Table 8: $\quad$ Dendogram for the chemical clusters

Finally the cluster membership using single linkage for the chemical industry is presented in Table A14.

\begin{tabular}{||l|c|c|c|c||}
\hline Label & Case & 4 clusters & 3 clusters & 2 clusters \\
\hline defender & 1 & 1 & 1 & 1 \\
\hline defender & 2 & 1 & 1 & 1 \\
\hline analyzer & 3 & 2 & 2 & 1 \\
\hline differentiation focus & 4 & 3 & 1 & 1 \\
\hline cost leadership & 5 & 4 & 3 & 1 \\
\hline differentiation focus & 6 & 3 & 1 & 1 \\
\hline cost focus & 7 & 4 & 3 & 1 \\
\hline differentiation & 8 & 3 & 1 \\
\hline
\end{tabular}

\section{Table A14: $\quad$ Cluster membership of chemical companies}

From the agglomeration schedule - which shows the stages of clustering and the proximity values at which items combine to form new clusters -, the dendogram - which graphically displays the stages of clustering - and the cluster membership, it can be concluded that four is the optimal number of clusters in the chemical industry. 


\begin{tabular}{|c|c|}
\hline Production system & $\begin{array}{l}\text { Woodward's } \\
(1965) \\
\text { categories }\end{array}$ \\
\hline 1. Unit production & \multirow{2}{*}{$\begin{array}{l}\text { Unit and small } \\
\text { batch } \\
\text { production }\end{array}$} \\
\hline 2. Small batch production & \\
\hline $\begin{array}{l}\text { 3. Production in large batches of standardized components subsequently } \\
\text { assembled diversely }\end{array}$ & \multirow{6}{*}{$\begin{array}{l}\text { Large batch } \\
\text { and mass } \\
\text { production }\end{array}$} \\
\hline 4. Mass production with no frequent product changes & \\
\hline 5. Mass production with frequent product changes & \\
\hline $\begin{array}{l}\text { 6. Production in large batches of standardized components subsequently } \\
\text { assembled diversely with features of small batch and continuous process } \\
\text { production }\end{array}$ & \\
\hline $\begin{array}{l}\text { 7. Production in large batches of standardized components subsequently } \\
\text { assembled diversely with also features of mass production with no frequent } \\
\text { product changes. }\end{array}$ & \\
\hline $\begin{array}{l}\text { 8. Mass production, with no frequent product changes in parts of the process } \\
\text { and parts with frequent product changes }\end{array}$ & \\
\hline $\begin{array}{l}\text { 9. Mass production with features of production in large batches of standardized } \\
\text { components as well as continuous process production }\end{array}$ & \multirow{4}{*}{$\begin{array}{l}\text { Continuous } \\
\text { process } \\
\text { production }\end{array}$} \\
\hline 10. Continuous process production & \\
\hline $\begin{array}{l}\text { 11. Continuous process production combined with mass production with no } \\
\text { frequent product changes where aspects of the process also have features of } \\
\text { mass production with frequent product changes }\end{array}$ & \\
\hline $\begin{array}{l}\text { 12. Continuous process production with features of mass production with no } \\
\text { frequent product changes }\end{array}$ & \\
\hline
\end{tabular}

Table 1: $\quad$ Assignment of production categories to Woodward's (1965) classification 


\begin{tabular}{|c|c|}
\hline $\begin{array}{l}\text { Advanced } \\
\text { manufacturing } \\
\text { technology }\end{array}$ & Developments perceived in the manufacturing environment \\
\hline 1. $C A D$ & $\begin{array}{l}\text { - Different production and design variants from standard are increasing }(p<0.09) \\
\text { - Management of materials, components and work-in-process is being decentralized } \\
\text { to work stations }(p<0.04) \\
\text { - Increasing specialization of skills is needed }(p<0.02)\end{array}$ \\
\hline 2. $\mathrm{CAE}$ & $\begin{array}{l}\text { - Time between the initial idea for new products and when they enter production is } \\
\text { becoming shorter }(p<0.08) \\
\text { - Products are becoming increasingly standardized }(p<0.04) \\
\text { - Inventory of work-in-process and of final products is being reduced }(p<0.09) \\
\text { - Management of materials, components and work-in-process is being decentralized } \\
\text { to work stations }(p<0.004)\end{array}$ \\
\hline 3. CAM & $\begin{array}{l}\text { - Number of people involved in design and development compared with those in } \\
\text { production increases }(p<0.05) \\
\text { - Increasing specialization of skills is needed }(p<0.04)\end{array}$ \\
\hline 4. CAPP & $\begin{array}{l}\text { - Production process stages are more closely integrated }(p<0.01) \\
\text { - Management of materials, components and work-in-process is being decentralized } \\
\text { to work stations }(p<0.09)\end{array}$ \\
\hline 5. $\mathrm{CNC}$ & $\begin{array}{l}\text { - Time between the initial idea of new products and when they enter production is } \\
\text { becoming shorter }(p<0.02) \\
\text { - Inventory of work-in-process and of final products is being reduced }(p<0.03) \\
\text { - Production process stages are more closely integrated }(p<0.05) \\
\text { - Number of people involved in planning and scheduling decreases compared to } \\
\text { those involved in production }(p<0.04) \\
\text { - Management of materials, components and work-in-process is being decentralized } \\
\text { to work stations }(p<0.05) \\
\text { - Due to the increasing complexity of the tasks, the amount of work that is } \\
\text { subcontracted increases }(p<0.08)\end{array}$ \\
\hline 6. CPS & $\begin{array}{l}\text { - Different production and design variants from standard are decreasing }(p<0.07) \\
\text { - Inventory of work-in-process and final products increases }(p<0.07) \\
\text { - Due to the increasing complexity of the tasks, the amount of work that is } \\
\text { subcontracted decreases }(p<0.04)\end{array}$ \\
\hline 7. FMS & $\begin{array}{l}\text { - Inventory of work-in-process and final products is being reduced }(p<0.05) \\
\text { - Management of materials, components and work-in-process is being decentralized } \\
\text { to work stations }(p<0.09)\end{array}$ \\
\hline 8. MRP & $\begin{array}{l}\text { - Products are becoming increasingly standardized }(p<0.04) \\
\text { - Inventory of work-in-process and of final products is being reduced }(p<0.007) \\
\text { - Production process stages are more closely integrated }(p<0.04)\end{array}$ \\
\hline 9. Robotics & $\begin{array}{l}\text { - Inventory of work-in-process and of final products is being reduced }(p<0.04) \\
\text { - Production process stages are more closely integrated }(p<0.03)\end{array}$ \\
\hline
\end{tabular}

Table 2: $\quad$ Significantly different developments in production technology when advanced manufacturing technologies are implemented 


\begin{tabular}{||l|l||}
\hline \hline Cluster & Alignment \\
\hline I & - Analyzer with automated large batch and mass production plus evolving HRM (\#9) \\
& - Analyzer with innovative large batch and mass production plus evolving HRM (\#10) \\
& - Analyzer with innovative large batch and mass production plus true HRM (\#11) \\
& - Analyzer with flexible large batch and mass production plus true HRM (\#12) \\
& plus true HRM (\#20)
\end{tabular}

Table 3: $\quad$ Three food \& drink clusters 


\begin{tabular}{|c|c|c|c|c|c|c|}
\hline $\begin{array}{l}\text { A: } \\
\text { F\&D } \\
\text { CLUSTER I }\end{array}$ & $\begin{array}{l}\text { Strategy- } \\
\text { environment fit }\end{array}$ & $\begin{array}{l}\text { Technology- } \\
\text { strategy fit }\end{array}$ & $\begin{array}{l}\text { Technology- } \\
\text { environment fit }\end{array}$ & $\begin{array}{l}\text { HRM- } \\
\text { strategy fit }\end{array}$ & $\begin{array}{l}\text { HRM- } \\
\text { environment fit }\end{array}$ & $\begin{array}{l}\text { Technology- } \\
\text { HRM fit }\end{array}$ \\
\hline Company 9 & $+/+$ & $-/-$ & $-1-$ & $+/+$ & $+/+$ & $+/+$ \\
\hline Company 10 & $+/+$ & $+/+$ & $+/+$ & $+/+$ & $+/+$ & $+/+$ \\
\hline Company 11 & $+/+$ & $+/+$ & $+/+$ & $+/+$ & $+/+$ & $+/+$ \\
\hline Company 12 & $+/+$ & $+/+$ & $+/+$ & $+/+$ & $+/+$ & $+/+$ \\
\hline Company 13 & $+/+$ & $+/+$ & $+/+$ & $+/+$ & $+/+$ & $+/+$ \\
\hline Company 20 & $+/+$ & ?? & ?? & $+/+$ & $+/+$ & ?? \\
\hline $\begin{array}{l}\text { B: } \\
\text { F\&D } \\
\text { CLUSTER II }\end{array}$ & $\begin{array}{l}\text { Strategy- } \\
\text { environment fit }\end{array}$ & $\begin{array}{l}\text { Technology- } \\
\text { strategy fit }\end{array}$ & $\begin{array}{l}\text { Technology- } \\
\text { environment fit }\end{array}$ & $\begin{array}{l}\text { HRM- } \\
\text { strategy fit }\end{array}$ & $\begin{array}{l}\text { HRM- } \\
\text { environment } \\
\text { fit }\end{array}$ & $\begin{array}{l}\text { Technology - } \\
\text { HRM fit }\end{array}$ \\
\hline Company 14 & $+/+$ & $+/+$ & $+/+$ & $+/+$ & $+/+$ & $+/+$ \\
\hline Company 16 & $-1-$ & $-1-$ & $+/+$ & $-/-$ & $+/+$ & $+/+$ \\
\hline Company 19 & $+/+$ & $+/+$ & $+/+$ & $+/+$ & $+/+$ & $+/+$ \\
\hline $\begin{array}{l}\text { C: } \\
\text { F\&D } \\
\text { CLUSTER III }\end{array}$ & $\begin{array}{l}\text { Strategy- } \\
\text { environment fit }\end{array}$ & $\begin{array}{l}\text { Technology- } \\
\text { strategy fit }\end{array}$ & $\begin{array}{l}\text { Technology- } \\
\text { environment fit }\end{array}$ & $\begin{array}{l}\text { HRM- } \\
\text { strategy fit }\end{array}$ & $\begin{array}{l}\text { HRM- } \\
\text { environment } \\
\text { fit }\end{array}$ & $\begin{array}{l}\text { Technology - } \\
\text { HRM fit }\end{array}$ \\
\hline Company 15 & $+/+$ & $+/-?$ & $+/-?$ & $+/-\quad ?$ & $+/-?$ & $+/+$ \\
\hline Company 17 & $-1-$ & $+/+$ & $+/+$ & $+/+$ & $+/+$ & $+/+$ \\
\hline Company 18 & $-1-$ & $+/+$ & $-1-$ & $-/-$ & $+/+$ & $-/-$ \\
\hline
\end{tabular}

Table 4: $\quad$ Different types of fit in food \& drink cluster I (A), II (B) and III (C) 


\begin{tabular}{||l|l|l||}
\hline Food \& drink industry & Cluster I & Cluster II \\
\hline Best performers & $10,11,12,13$ & 14,19 \\
\hline
\end{tabular}

Table 5: $\quad$ Hypotheses on performance implications in food \& drink industry 


\begin{tabular}{||l|l||}
\hline Cluster & Alignment \\
\hline I & - Defender with flexible continuous process production plus imposed HRM (\#1) \\
& - Defender with flexible large batch and mass production plus traditional personnel management (\#2) \\
\hline II & - Analyzer with innovative large batch and mass production plus true HRM (\#3) \\
\hline III & - Differentiation focus strategy with modified large batch and mass production plus evolving HRM (\#4) \\
& - Differentiation focus strategy with automated continuous process production plus evolving HRM (\#6) \\
\hline IV & $-\begin{array}{l}\text { Cost leadership strategy with automated continuous process production plus traditional personnel } \\
\text { management (\#5) }\end{array}$ \\
\hline & $\begin{array}{l}\text { Cost focus strategy with flexible continuous process production plus traditional personnel management } \\
(\# 7)\end{array}$ \\
\hline
\end{tabular}

Table 6: $\quad$ Four chemical clusters 


\begin{tabular}{|c|c|c|c|c|c|c|}
\hline $\begin{array}{l}\text { A: } \\
\text { CHEMICAL } \\
\text { CLUSTER I }\end{array}$ & $\begin{array}{l}\text { Strategy- } \\
\text { environment fit }\end{array}$ & $\begin{array}{l}\text { Technology- } \\
\text { strategy fit }\end{array}$ & $\begin{array}{l}\text { Technology- } \\
\text { environment } \\
\text { fit }\end{array}$ & $\begin{array}{l}\text { HRM- } \\
\text { strategy fit }\end{array}$ & $\begin{array}{l}\text { HRM- } \\
\text { environment } \\
\text { fit }\end{array}$ & $\begin{array}{l}\text { Technology - } \\
\text { HRM fit }\end{array}$ \\
\hline Company 1 & $-/-$ & $-/-$ & $+/+$ & $+/+$ & $+/-?$ & $+/+$ \\
\hline Company 2 & $-1-$ & $-1-$ & $+/+$ & $+/+$ & $-/-$ & $-/-$ \\
\hline $\begin{array}{l}\text { B: } \\
\text { CHEMICAL } \\
\text { CLUSTER II }\end{array}$ & $\begin{array}{l}\text { Strategy- } \\
\text { environment fit }\end{array}$ & $\begin{array}{l}\text { Technology- } \\
\text { strategy fit }\end{array}$ & $\begin{array}{l}\text { Technology- } \\
\text { environment } \\
\text { fit }\end{array}$ & $\begin{array}{l}\text { HRM- } \\
\text { strategy fit }\end{array}$ & $\begin{array}{l}\text { HRM- } \\
\text { environment } \\
\text { fit }\end{array}$ & $\begin{array}{l}\text { Technology - } \\
\text { HRM fit }\end{array}$ \\
\hline Company 3 & $+/+$ & $+/+$ & $+1+$ & $+/+$ & $+/+$ & $+1+$ \\
\hline $\begin{array}{l}\text { C: } \\
\text { CHEMICAL } \\
\text { CLUSTER } \\
\text { III } \\
\end{array}$ & $\begin{array}{l}\text { Strategy- } \\
\text { environment fit }\end{array}$ & $\begin{array}{l}\text { Technology- } \\
\text { strategy fit }\end{array}$ & $\begin{array}{l}\text { Technology- } \\
\text { environment } \\
\text { fit }\end{array}$ & $\begin{array}{l}\text { HRM- } \\
\text { strategy fit }\end{array}$ & $\begin{array}{l}\text { HRM- } \\
\text { environment } \\
\text { fit }\end{array}$ & $\begin{array}{l}\text { Technology - } \\
\text { HRM fit }\end{array}$ \\
\hline Company 4 & $+/+$ & $-/-$ & $-/-$ & $+/+$ & $+/+$ & $-/-$ \\
\hline Company 6 & $-1-$ & $-/-$ & $+/+$ & $+/+$ & $+/-?$ & $-/-$ \\
\hline Company 8 & $-/-$ & ?? & ?? & $+/+$ & $+/-?$ & ?? \\
\hline $\begin{array}{l}\text { D: } \\
\text { CHEMICAL } \\
\text { CLUSTER } \\
\text { IV }\end{array}$ & $\begin{array}{l}\text { Strategy- } \\
\text { environment fit }\end{array}$ & $\begin{array}{l}\text { Technology- } \\
\text { strategy fit }\end{array}$ & $\begin{array}{l}\text { Technology- } \\
\text { environment } \\
\text { fit }\end{array}$ & $\begin{array}{l}\text { HRM- } \\
\text { strategy fit }\end{array}$ & $\begin{array}{l}\text { HRM- } \\
\text { environment } \\
\text { fit }\end{array}$ & $\begin{array}{l}\text { Technology - } \\
\text { HRM fit }\end{array}$ \\
\hline Company 5 & $+/+$ & $+/+$ & $+/+$ & $+/+$ & $+/+$ & $+/+$ \\
\hline Company 7 & $+/+$ & $+/-?$ & $+/-?$ & $+/+$ & $+/+$ & $-/-$ \\
\hline
\end{tabular}

Table 7: $\quad$ Different types of fit in chemical cluster I (A), II (B), III (C) and IV (D) 


\begin{tabular}{||l|l|l||}
\hline \hline Chemical Industry & Cluster II & Cluster IV \\
\hline Best performers & 3 & 5 \\
\hline
\end{tabular}

Table 8: $\quad$ Hypotheses on performance implications in chemical industry 


\begin{tabular}{||l|c|c|c|c||}
\hline \hline Industry per country & Average ROS & Standard deviation & Minimum ROS & Maximum ROS \\
\hline $\begin{array}{l}\text { Dutch food \& drink } \\
\text { industry ( } \mathrm{n}=5)\end{array}$ & 0.07 & 0.05 & -0.01 & 0.13 \\
\hline $\begin{array}{l}\text { British food \& drink } \\
\text { industry ( } \mathrm{n}=5)\end{array}$ & 0.10 & 0.02 & 0.08 & 0.12 \\
\hline $\begin{array}{l}\text { Dutch chemical industry } \\
(\mathrm{n}=5)\end{array}$ & 0.02 & 0.03 & -0.03 & 0.05 \\
\hline $\begin{array}{l}\text { British chemical industry } \\
(\mathrm{n}=3)\end{array}$ & 0.12 & 0.11 & 0.01 & 0.23 \\
\hline
\end{tabular}

Table 9: $\quad$ Return on Sales (ROS) per industry and country 


\begin{tabular}{|c|c|c|c|c|}
\hline $\begin{array}{l}\text { A: } \\
\text { Food \& drink } \\
\text { industry }\end{array}$ & Company number & Nationality & $\begin{array}{l}\text { ROS of the } \\
\text { company }\end{array}$ & $\begin{array}{l}\text { Average national } \\
\text { industry ROS }\end{array}$ \\
\hline \multirow[t]{6}{*}{ CLUSTER I } & 9 & British & 0.08 & 0.10 \\
\hline & 10 & British & 0.12 & 0.10 \\
\hline & 11 & British & 0.12 & 0.10 \\
\hline & 12 & British & 0.08 & 0.10 \\
\hline & 13 & British & 0.10 & 0.10 \\
\hline & 20 & Dutch & 0.07 & 0.07 \\
\hline \multirow[t]{3}{*}{ CLUSTER II } & 14 & Dutch & 0.09 & 0.07 \\
\hline & 16 & Dutch & 0.05 & 0.07 \\
\hline & 19 & Dutch & Missing & 0.07 \\
\hline \multirow[t]{3}{*}{ CLUSTER III } & 15 & Dutch & 0.13 & 0.07 \\
\hline & 17 & Dutch & Missing & 0.07 \\
\hline & 18 & Dutch & -0.01 & 0.07 \\
\hline $\begin{array}{l}\text { B: } \\
\text { Chemical } \\
\text { industry }\end{array}$ & Company number & Nationality & $\begin{array}{l}\text { ROS per } \\
\text { company }\end{array}$ & $\begin{array}{l}\text { Average national } \\
\text { industry ROS }\end{array}$ \\
\hline \multirow[t]{2}{*}{ CLUSTER I } & 1 & British & 0.23 & 0.12 \\
\hline & 2 & British & 0.01 & 0.12 \\
\hline CLUSTER II & 3 & British & 0.12 & 0.12 \\
\hline \multirow[t]{3}{*}{ CLUSTER III } & 4 & Dutch & 0.01 & 0.02 \\
\hline & 6 & Dutch & -0.03 & 0.02 \\
\hline & 8 & Dutch & 0.03 & 0.02 \\
\hline \multirow[t]{2}{*}{ CLUSTER IV } & 5 & Dutch & 0.05 & 0.02 \\
\hline & 7 & Dutch & 0.05 & 0.02 \\
\hline
\end{tabular}

Table 10: $\quad$ ROS per company per food and drink (A) and chemical cluster (B) 